\title{
EFFECTS OF A MULTIFACETED CLASSROOM INTERVENTION ON RACIAL DISPROPORTIONALITY
}

\author{
by \\ CODY GION
}

\author{
A DISSERTATION \\ Presented to the Department of Special Education and Clinical Sciences \\ and the Graduate School of the University of Oregon \\ in partial fulfillment of the requirements \\ for the degree of \\ Doctor of Philosophy
}

September 2018 


\section{DISSERTATION APPROVAL PAGE}

\section{Student: Cody Gion}

Title: Effects of a Multifaceted Classroom Intervention on Racial Disproportionality

This dissertation has been accepted and approved in partial fulfillment of the requirements for the Doctor of Special Education degree in the College of Education Special Education Department by:

Kent McIntosh Chairperson and Advisor

Tary Tobin Core Member

Valerie Mazzotti Core Member

Erik Girvan Institutional Representative

and

Janet Woodruff-Borden, Vice Provost and Dean of the Graduate School

Original approval signatures are on file with the University of Oregon Graduate School.

Degree awarded September 2018 
C 2018 Cody Gion 


\section{DISSERTATION ABSTRACT}

\section{Cody Gion}

Doctor of Philosophy

Department of Special Education and Clinical Sciences

September 2018

Title: Effects of a Multifaceted Classroom Intervention on Racial Disproportionality

The present study is an examination of a classroom based intervention with five critical components of (a) defining and teaching desired behavior with cultural consideration, (b) increasing acknowledgement for African American students, (c) responding to unwanted behavior using an instructional approach, (d) using disaggregated data by race to guide intervention implementation, and (e) providing coaching to enhance intervention implementation. The study is a concurrent multiple-baseline single-case design across four general education teachers ranging from kindergarten to seventh grade. Results from the study indicate a functional relation between intervention implementation and increased rates of praise and decreased rates of reprimands for African American students. In addition, data show equitable increases in praise across both racial groups and decreases in reprimand disparities between racial groups during intervention. Teachers implementing the intervention found it to be acceptable, effective, and a good fit within their school and classroom contexts. The findings from this study suggest this intervention may help to close the discipline gap between African American students and their peers. 
CURRICULUM VITAE

NAME OF AUTHOR: Cody Gion

\section{GRADUATE AND UNDERGRADUATE SCHOOLS ATTENDED:}

University of Oregon, Eugene, OR

University of Montana, Missoula, MT

Williston State University, Williston, ND

\section{DEGREES AWARDED:}

Doctor of Philosophy, Special Education, 2018, University of Oregon

Master of Science, School Psychology, 2014, University of Oregon

Bachelor of Arts, Psychology, 2010, University of Montana

\section{AREAS OF SPECIAL INTEREST:}

Equity in School Discipline

Implementation Science

Professional Development

PROFESSIONAL EXPERIENCE:

Special Education Program Director, Gresham-Barlow School District, Gresham, Oregon, 2018-Present

Adjunct Professor, Portland State University, Portland, Oregon, 2018-Present

Professional Consultant, Independent Contractor, Various Locations, 2013Present

Student Researcher, University of Oregon, Eugene, Oregon 2016-2017

Intern., Safe and Civil Schools, Eugene, Oregon, 2016

Graduate Teaching Fellow, University of Oregon, Eugene, Oregon, 2012-2013 \& 2015-2016

School Psychologist, Clark County School District, Las Vegas, Nevada, 20142015 
GRANTS, AWARDS, AND HONORS:

General University Scholarship, University of Oregon, Eugene, Oregon, 20172018

Hill M. Walker Legacy Scholarship Award, University of Oregon College of Education, Eugene, Oregon, 2017 - 2018

St. Labre Indian Catholic School Graduate Student Scholarship Award, St. Labre Indian Catholic School, Ashland, Montana, 2011-2012, 2012-2013, 20152016, 2016-2017, \& 2017-2018

Dynamic Measurement Group (DIBELS) Scholarship Award, University of Oregon College of Education, Eugene, Oregon, 2012-2013, 2013-2014, 2016-2017, \& 2017-2018

College of Education Travel Grant, University of Oregon, Eugene, Oregon, 2017

School Psychology Department Travel Grant, University of Oregon, Eugene, Oregon, 2013

Haynes Foundation Scholarship Award, University of Montana, Missoula, Montana, 2007-2008, 2008-2009, \& 2009-2010

Williston State College Men's Basketball Scholarship, Williston State College, Williston, North Dakota, 2006-2007

Montana University System Honor Scholarship, Montana University System, Helena, Montana, 2006-2007

\section{PUBLICATIONS:}

Gion, C., Nese R., Massar, M., Kato, M., George, H., \& McIntosh, K. (in press). Positive Behavior Interventions and Supports. Chapter in The Check \& Connect Model: Universal Principles and Targeted Interventions to Promote Graduation for All. Springer

Gion, C., McIntosh, K., \& Smolkowski, K. (2018). Examination of American Indian and Alaska Native Office Discipline Referral Disproportionality Using the Vulnerable Decision Points Model. Behavior Disorders, 0198742918773438.

Kittelman, A., Gion, C., Horner, R. H., Levin, J. R., \& Kratochwill, T. R. (2018). Establishing Journalistic Standards for the Publication of Negative Results. Remedial and Special Education, 0741932517745491. 
McIntosh, K., Gion, C., \& Bastable, E. (2018). Do schools implementing SWPBIS have decreased racial and ethnic disproportionality in school discipline? PBIS evaluation brief. Eugene, OR: OSEP National Technical Assistance Center on Positive Behavioral Interventions and Supports.

Girvan, E. J., Gion, C., McIntosh, K., \& Smolkowski, K. (2016). The relative contribution of subjective office referrals to racial disproportionality in school discipline. School Psychology Quarterly, 32(3), 392.

Gion, C., McIntosh, K., \& Horner, R. H. (2014). Patterns of minor office discipline referrals in schools using SWIS. PBIS evaluation brief. Eugene, OR: OSEP National Technical Assistance Center on Positive Behavioral Interventions and Supports. 


\section{ACKNOWLEDGMENTS}

My journey up to this point has been fueled by a large community of support. I am forever grateful to the University of Oregon College of Education. Additionally, I am thankful for the entire Education Community Supports (ECS) organization. I have been struck by your exemplary kindness, and for the numerous opportunities you have provided me.

I would not have succeeded without backing from a host of individuals. I need to thank Dr. Christopher Murray who has singled me out to participate on multiple leadership grants throughout my doctoral program. I could not have completed graduate school without this financial support. I would like to thank Emily Cornell, Dr. Roland Good, Dr. Ruth Kaminski, Dr. Hill Walker, Dr. Anne Todd, Dr. Laura Lee McIntyre, Dr. Angela Whalen, Dr. Rhonda Nese, Dr. Joe Nese, Dr. Robert Horner, Kathleen Jungjohann, Dr. Beth Harn, Dr. John Seeley, and Dr. Claudia Vincent for going out of your way to find value in who I am. I want to thank all the faculty, staff, and students at the University of Oregon that I have had the pleasure to build relationships with over the years. In addition, I wish to express sincere appreciation for my dissertation committee:

Dr. Erik Girvan, Dr. Tary Tobin, and Dr. Valerie Mazzotti. I am grateful for your compassion, support, and understanding throughout this process.

Finally, I need to thank my advisor, Dr. Kent McIntosh, for his tremendous support and assistance in the preparation of this manuscript and throughout my graduate career. I could not have asked for a better mentor. I have learned a lot from Dr. McIntosh about scholarship, but have learned more about the important qualities of showing kindness, transparency, and supportiveness for all people. 
The development of this research was supported by the Institute of Education Sciences, U.S. Department of Education (\#R324A170034). 


\section{TABLE OF CONTENTS}

Chapter

Page

I. LITERATURE REVIEW …..................................................................

The Impact of Race on Exclusionary Discipline ........................................... 2

Targets for Intervention ...................................................................... 2

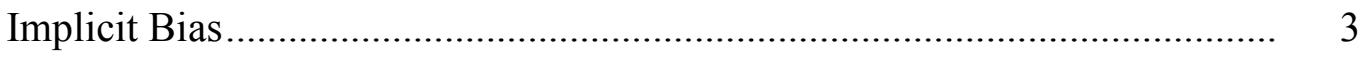

Teacher-Student Interactions …........................................................ 4

Promising Interventions ......................................................................... 5

School-Wide Positive Behavioral Interventions and Supports (SWPBIS)...... 5

Classroom-Based Teacher Interventions ............................................... 7

Defining Elements of the Multifaceted Classroom Intervention ........................ 9

Define and Teach Desired Behavior with Cultural Considerations................ 10

Increase Acknowledgement for African American Students........................ 11

Respond to Unwanted Behavior Using an Instructional Approach ............... 11

Use Disaggregated Data by Race......................................................... 12

Provide Coaching to Support Intervention Implementation ......................... 12

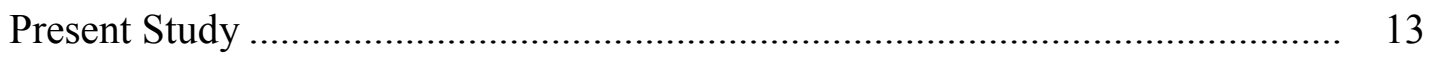

Research Questions ....................................................................... 13

II. METHOD …..................................................................................... 15

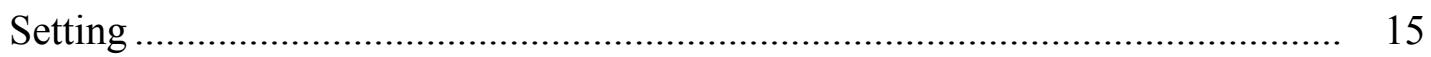




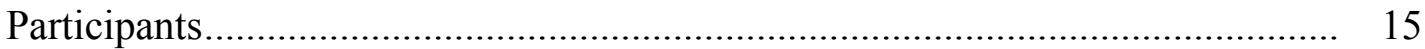

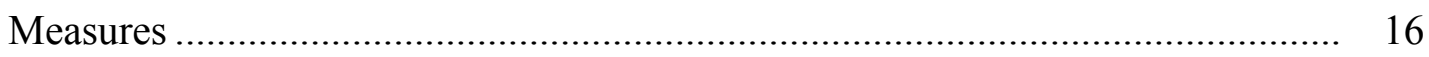

Observation of Teacher Behavior ......................................................... 16

Office Discipline Referrals (ODRs) ........................................................... 19

Culturally Responsive - Classroom Observation Checklist (CR-COC) ............ 19

Primary Intervention Rating Scale (PIRS) .................................................. 20

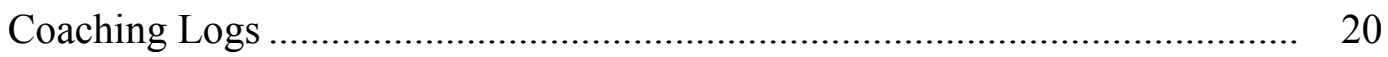

Inter-Observer Agreement (IOA) ………............................................... 20

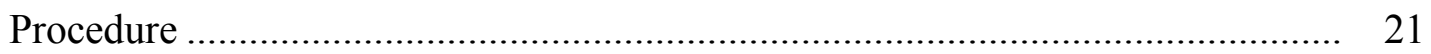

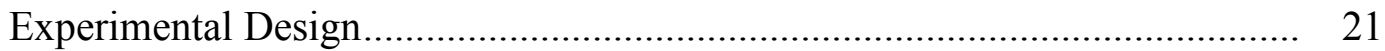

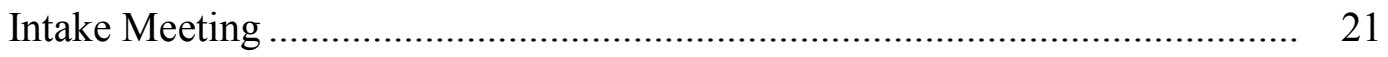

Baseline Phase ………......................................................................... 22

Intervention Phase (............................................................................... 22

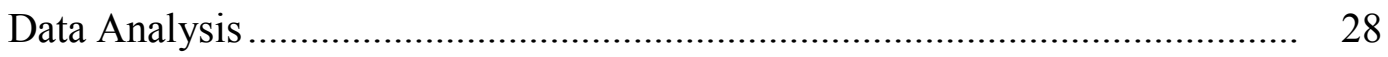

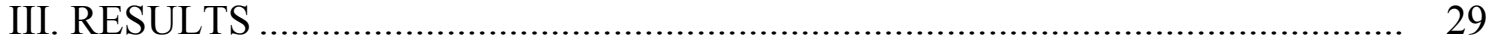

Inter-Observer Agreement (IOA) ……………………............................... 32

Office Discipline Referrals (ODRs)................................................................ 32

Culturally Responsive - Classroom Observation Checklist (CR-COC)) ............... 32

Coaching Logs ……............................................................................. 33

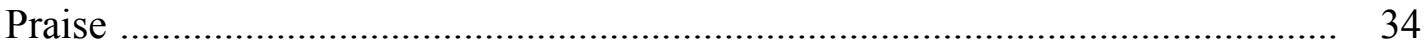

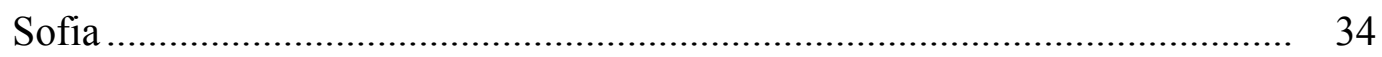

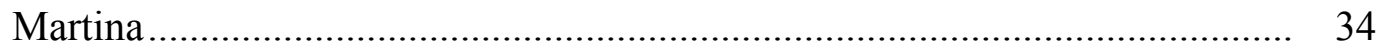


Chapter Page

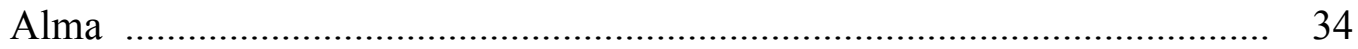

Orien ......................................................................................... 35

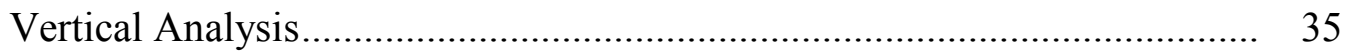

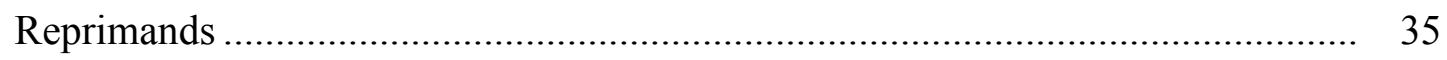

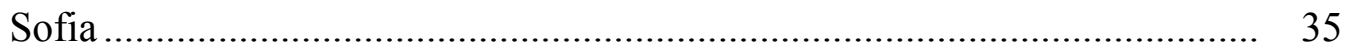

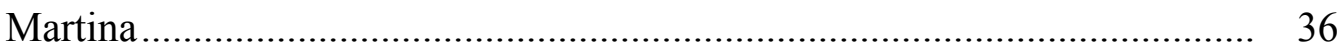

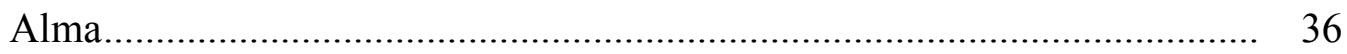

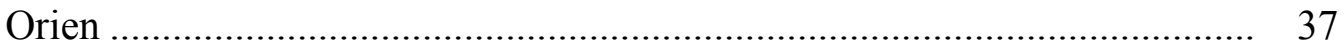

Vertical Analysis....................................................................... 37

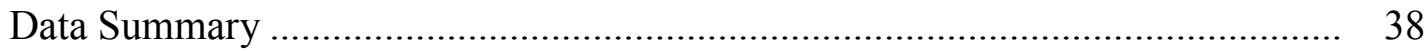

Primary Intervention Rating Scale (PIRS) ........................................... 38

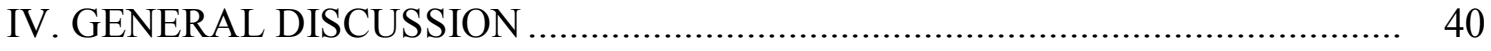

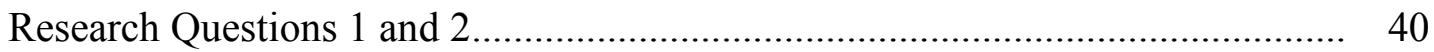

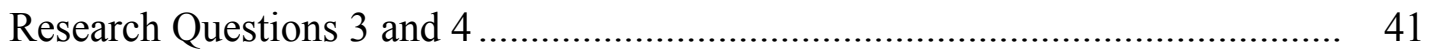

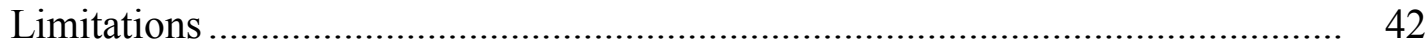

Future Directions and Implications for Research and Practice........................ 43

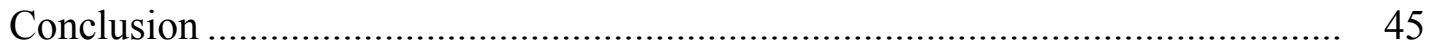




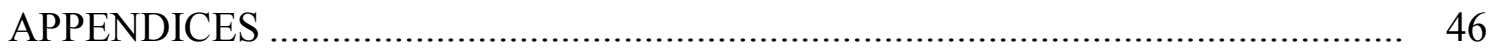

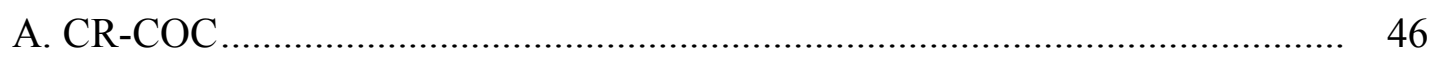

B. PRIMARY INTERVENTION RATING SCALE (PIRS) ............................... 48

C. COACH CONTACT LOG .................................................................... 50

D. TEACHER INTAKE INTERVIEW ....................................................... 51

E. ACTION PLANNING MEETING_........................................................... 56

F. STUDENT PERSONAL MATRIX ACTIVITY ............................................. 60

G. PRAISE PREFERENCE ASSESSMENT ACTIVITY .................................... 61

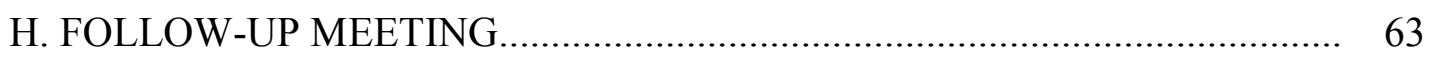

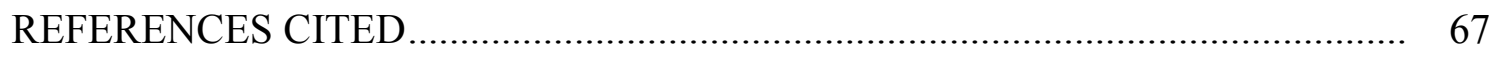




\section{LIST OF FIGURES}

Figure Page

1. Coercive Cycle of Inequities.................................................................. 5

2. Constructive Cycle of Increasing Equity ................................................. 9

3. Ratio of Teacher Praise to Reprimands By Race........................................... 29

4. Frequency Rates for Teacher Praise Per Student Across Classrooms................. 30

5. Frequency Rates for Teacher Reprimands Per Student Across Classrooms.......... 31

6. Primary Intervention Rating Scale (PIRS) Results ...................................... 39 


\section{LIST OF TABLES}

Table

Page

1. Average Implementation Across Phases........................................................ 33 


\section{CHAPTER I}

\section{LITERATURE REVIEW}

Research continues to demonstrate the harmful effects of high rates of exclusionary discipline practices (e.g., suspensions, expulsions, and Office Discipline Referrals) for individual students and for entire school systems. Students who experience high rates of exclusion are more likely to have future behavioral problems, dropout, and be involved with juvenile justice systems than students who experience low rates of exclusion (Ekstrom, Goertz, Pollack, \& Rock, 1986; Nicholson-Crotty, Birchmeier, \& Valentine, 2009; Raffaele Mendez, 2003; Tobin, Sugai, \& Colvin, 1996). When students are removed from the educational environment, they miss out on critical academic and social content and are often reinforced for escaping unwanted tasks. Exclusionary discipline is an ineffective and reactive approach to changing student behavior that only serves to exacerbate behavioral skill deficits.

Although some perceive that the costs of exclusionary discipline for the individual student is outweighed by the benefits for other students within the educational environment, the opposite seems to be true. Excluding students who misbehave has detrimental effects on the entire school systems. School systems with high rates of exclusionary discipline tend to have lower overall academic achievement and poorer ratings of school governance and climate than schools with lower exclusion rates (American Psychological Association, 2008). School systems that rely solely on exclusionary practices will fail in their attempts to improve behavior for individual students and will be ineffective in creating an environment that maximizes student learning for all. 


\section{The Impact of Race on Exclusionary Discipline}

The most disturbing characteristic of the overuse of exclusionary discipline is that it is disproportionally distributed to students who are African American. African American students in the United States are two-to-three times more likely to receive Office Discipline Referrals (ODRs), be suspended, and be expelled than any other racial group (Anyon et al., 2014; Losen, Hodson, Keith, Morrison, \& Belway, 2015). This means that African American students miss more instructional time than other groups due to unwanted behavior. This excessive removal from the educational environment may be contributing to the achievement gap between African American students and their peers (Gregory, Skiba, \& Noguera, 2010). If we are to improve the achievement gap for African American students, then we must focus on improving the discipline gap for these same students.

The issue of discipline disproportionality is concerning, considering that race seems to be the primary factor in determining disproportionality. Researchers have examined whether race predicts exclusionary discipline above and beyond other factors behavior, socioeconomic status, and school characteristics (e.g., school size, socioeconomic status), and they have found that even when controlling for these characteristics, being African American predicts whether or not a student is more likely to experience exclusionary discipline (Bradshaw, Mitchell, O'Brennan, \& Leaf, 2010; Rocque, 2010). Disproportionate exclusionary discipline seems to be indeed a racial issue and cannot simply be explained away by other factors.

\section{Targets for Intervention}


To understand this problem fully, it is important to consider the variables that may be contributing to these racial inequalities. Most educators understand the harmful impact of exclusionary discipline and understand the inequities in academic achievement between racial groups in our education system. Many entered the field of education looking to improve student equity for all students, and it seems unlikely that most educators would have explicit prejudices toward African American students. The research to date seems to support this claim.

Implicit bias. A series of studies support the idea that disproportionality is primarily driven by implicit biases (i.e., unconscious attitudes or stereotypes) as opposed to overt explicit racism. For example, Girvan, Gion, McIntosh, and Smolkowski (2016) examined whether subjective ODRs (e.g., defiance, disrespect, and disruption) contributed to disproportionality more than objective ODRs (e.g., fighting, smoking). They found that subjective referrals were substantially more predictive than objective referrals of ODR disproportionality, indicating the ambiguity of defining problem behavior may be contributing more toward disproportionality rather than a universal targeting of African American students.

Additionally, Skiba et al. (2014) investigated what factors contribute to disproportionality and found that the problem seems to be multifaceted. Type of infraction, school characteristics, and student characteristics were all predictors of exclusionary discipline, meaning it depends partly interaction of these factors whether disproportionality will occur. Smolkowski, Girvan, Mcintosh, Nese, and Horner (2016) found that disproportionality depended upon time of day, location, severity of infraction, and by gender in addition to race, suggesting again an interaction between student race 
and environmental variables. If disproportionality was driven solely by explicit racism these factors would have little weight and solutions to disproportionality would be simplified.

These studies seem to indicate that disproportionality in school discipline for African American students is fluid and complex and not static. There is not one reason for discipline disproportionality, but instead it seems to depend on many environmental influences, as well as student and teacher characteristics, information that seems to suggest that manipulation of malleable environmental factors may lead to a reduction in disproportionality.

Teacher-student interactions. One primary contributing factor to disproportionality may be a coercive cycle of teacher-student interactions. Teacherstudent interactions can be considered symbiotic, with the nature of these interactions influencing teacher and student behavior in a coercive or constructive way (Patterson, 1982). Excessive attention to unwanted behavior and lack of attention to desired behavior may reinforce unwanted behavior, resulting in a coercive cycle of teacher-student interactions.

This coercive cycle could serve to strengthen negative racial biases and result in increasing rates of exclusionary discipline for African American students. Figure 1 depicts a conceptual model of this coercive cycle that may be responsible for discipline disproportionality. Assuming environmental influences can strengthen negative implicit biases, research may want to look at manipulating environmental factors to promote a more constructive cycle and improve discipline equity for African American students. 
Figure 1. Coercive Cycle of Inequities

\begin{tabular}{|c|c|c|c|}
\hline Setting Event & Antecedent & Behavior & Consequence \\
\hline $\begin{array}{l}\text { Few positive } \\
\text { interactions }\end{array}$ & $\begin{array}{l}\text { Negative } \\
\text { interactions, } \\
\text { perceived } \\
\text { slights, } \\
\text { conflict with } \\
\text { adults }\end{array}$ & $\begin{array}{l}\text { Student } \\
\text { engages in } \\
\text { unwanted } \\
\text { or } \\
\text { unexpected } \\
\text { behavior }\end{array}$ & $\begin{array}{l}\text { Student sent to } \\
\text { office (escapes } \\
\text { social } \\
\text { interaction) }\end{array}$ \\
\hline
\end{tabular}

Behavior summary statement for exclusionary discipline disproportionality adapted from (McIntosh, Girvan, Horner, \& Smolkowski, 2014).

A recent study provides support for the credibility of the coercive cycle of inequities. Scott, Gage, Hirn, and Han (2018) found that African American students received more negative feedback from teachers than their White counterparts regardless of their behavior. Further, this effect was seen across both African American and White teachers. The researchers also theorized that disproportionate negative interactions between teachers and African American students could contribute to disproportionate use of exclusionary discipline in response to unwanted behavior and that the relationship between teacher interactions and student behavior was reciprocal in nature.

\section{Promising Interventions}

Studies have started to take an experimental approach to improving discipline disproportionality for African American students. These school-based approaches focused on proactive environmental manipulations of teacher behavior to reduce discipline disproportionality for African American student populations. In reviewing previous research, the following promising approaches have emerged.

School-Wide Positive Behavioral Interventions and Supports (SWPBIS). SWPBIS is considered a well-established a framework for reducing ineffective 
exclusionary discipline practices and improving behavior and academic outcomes across various school contexts (e.g., Algozzine \& Algozzine, 2007; Bradshaw, Mitchell, \& Leaf, 2010; Freeman et al., 2016; Horner et al., 2009). SWPBIS consists of defining elements that are preventative, proactive, and instructional in nature (Sugai \& Horner, 2002). Core elements of SWPBIS include (a) building systems of support, (b) collecting and using data for decision making, (c) defining meaningful and measurable outcomes, and (d) using evidence-based practices (Sugai \& Horner, 2002, 2009; Sugai, Horner, \& McIntosh, 2008).

Previous research supports a positive impact of SWPBIS implementation on discipline disproportionality for African American students, in addition to its overall effectiveness. For example, Vincent, Swain-Bradway, Tobin, and May (2011) compared racial disproportionality of ODRs between elementary schools implementing SWPBIS to fidelity and schools not implementing SWPBIS across a 3-year timeframe. Their findings indicated a reduction in ODR disproportionality for African American students for schools implementing SWPBIS. In addition, McIntosh, Gion, and Bastable (2018) compared OSS risk rates for African American students for schools implementing SWPBIS and overall OSS risk rates for African American students in schools throughout the United States. They found schools implementing SWPBIS with fidelity tended to have lower OSS risk rates for African American students compared to all other schools.

Although SWPBIS seems to be associated with reductions in discipline disproportionality for African American students, there is also evidence to suggest that SWPBIS implementation, without modification, is insufficient in eliminating discipline disproportionality for African American students. Previous research suggests that 
although SWPBIS may reduce the rates of exclusionary discipline in general, and may also reduce discipline disproportionality, inequities still exist for African American students when compared to students from other racial backgrounds (McIntosh, Gion, et al., 2018; Vincent \& Tobin, 2011). The remaining discipline gap for African American students may suggest that critical components of SWPBIS need to be intensified or modified.

Recent research has begun to focus on adapting traditional behavioral supports to improve outcomes for African American students. The features of (a) focusing on the classroom context, (b) defining and teaching desired behavior with a focus on cultural considerations, (c) increasing acknowledgement for African American students, (d) responding to unwanted behavior with an instructional approach, (e) using disaggregated data by race to guide intervention selection and implementation, and (f) supporting the implementation of effective classroom-based interventions with coaching are beginning to show merit as potential enhancements to the SWPBIS framework.

Classroom-based teacher interventions. The classroom is where most unwanted behavior occurs resulting in the highest rates of exclusionary discipline and disproportionality (Gion, McIntosh, \& Horner, 2014; Smolkowski et al., 2016). Additionally, the implementation of proactive and supportive classroom systems within SWPBIS is one of the largest predicators of equity in school discipline (Vincent \& Tobin, 2011). Thus, a focus on intensifying and adapting supports within the classroom environment may have the most direct impact on discipline disproportionality.

Recent research focusing on improving equity within classroom environments has shown promise. Gregory et al. (2016) aimed to close the discipline gap for African 
American students by implementing a classroom intervention focused on improving classroom emotional support, organization, and instructional support. These researchers conducted a randomized controlled trial across 86 secondary classrooms. Teachers were coached to implement a comprehensive classroom support system across a two-year span. Classroom teachers who received intervention showed no differences between their use of ODRs for African American and other students.

In another classroom-based study, Bradshaw et al. (2018) implemented an intervention that consisted of school professional development and individual classroom coaching to improve equity for African American students. This randomized controlled trial was conducted with 158 elementary and middle school teachers from schools across the state of Maryland. Results indicated significant improvement in proactive behavior management and student cooperation and reductions in student disruptive behavior for students who are African American.

The last classroom-based intervention included in this review showed a reduction in ODRs for African American male students by two-thirds and improved connections to their school environments (Cook et al., 2018). The study was a single-case multiple baseline across four different schools. The ODR rates and school connectedness measures were compared before and after intervention. The intervention consisted of teacher professional development focused on the core components of (a) proactive classroom management, (b) self-regulation strategies, and (c) reactive strategies aimed to improve teacher empathy, consistency, and appropriateness of responding to unwanted behavior. 


\section{Defining Elements of the Multifaceted Classroom Intervention}

The approaches from previous experimental research to improve discipline equity have shaped the intervention used in this study. The researcher utilized common themes of previous practice in hopes of maximizing intervention effectiveness and efficiency. The intervention used in this study relied on five defining elements: (a) define and teach desired behavior with cultural considerations, (b) increase acknowledgement for African American students, (c) respond to unwanted behavior using an instructional approach, (d) use disaggregated data by race to guide intervention implementation, and (e) provide coaching to enhance intervention implementation. The implementation of these elements may serve to form constructive cycle of increasing equity (Figure 2), based upon a reciprocal relationship between positive teacher attention and desired student behavior as opposed to the theorized coercive cycle of inequity displayed in Figure 1.

Figure 2. Constructive Cycle of Increasing Equity

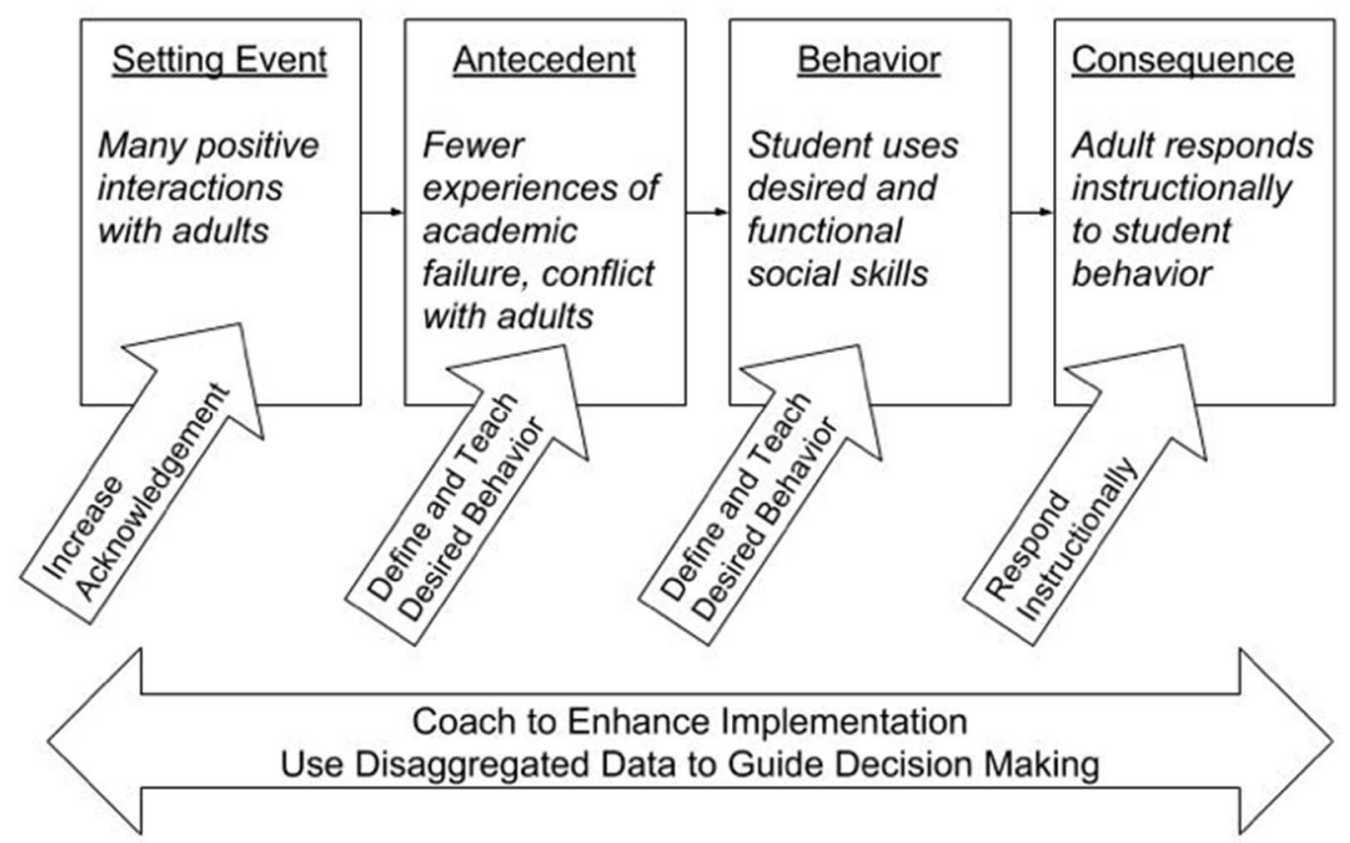

Behavioral summary for equitable behavioral supports adapted from (McIntosh et al., 2014). 
Define and teach desired behavior with cultural considerations. One element of the classroom system that needs more attention is defining and teaching desired behavior with consideration for cultural differences for students within the classroom environment. Teaching three to five positively-stated behavior expectations to students is a wellestablished intervention to prevent unwanted behavior at the classroom level (Simonsen, Fairbanks, Briesch, Myers, \& Sugai, 2008). What has not been well-established, however, is the appropriateness of classroom behavioral expectations for students from diverse backgrounds.

Subjective classroom behaviors are the biggest contributor to African American disproportionality, highlighting the importance of explicitly defining desired behavior with consideration for students' cultures and backgrounds (Girvan et al., 2016; Smolkowski et al., 2016). Individuals judge the appropriateness of others' behavior based on the bias from their own background and experiences. Teachers throughout the United States are mostly White and female (Taie \& Goldring, 2017), and it is reasonable to think that many teachers come from backgrounds that are different from the African American students they teach, leading to differences in determinations of acceptable and unacceptable behavior.

In a case study conducted by McIntosh, Ellwood, McCall, and Girvan (2018), school ODR data, disaggregated by race, was used to identify the primary context in which disproportionality was most likely to occur. The school team identified a discrepancy between adult expectations and student expectations for physical aggression on the playground. The school team in this case chose to redefine and explicitly teach playground expectations with consideration for students' cultural backgrounds and 
experiences. The result to this approach that led to the elimination of racial disproportionality within this setting.

It has been suggested that educators examine their behavioral expectations for their cultural sensitivity by obtaining student input and shaping expectations around the understanding of their students diverse experiences (Leverson, Smith, McIntosh, Rose, \& Pinkelman, 2016). In this study, we took this information into account and structured systematic ways for teachers to obtain student input and reflect on how their classroom expectations were similar to, and different from, the expectations in their home and neighborhood settings.

Increase acknowledgement for African American students. Students who receive more attention for unwanted behavior (i.e., reprimands) than for desired behavior (i.e., praise) are more likely to have problems with emotion regulation and concentration, and are more likely to display disruptive behaviors than students who receive more attention for desired behavior (Reinke, Herman, \& Newcomer, 2016). Additionally, appropriate use of praise and reprimands have been associated with reductions in problem behavior, increases in prosocial behaviors, and increases in academic achievement (Floress, Jenkins, Reinke, \& McKown, 2017; MacSuga-Gage \& Simonsen, 2015; Simonsen et al., 2008).

Respond to unwanted behavior using an instructional approach. An effective strategy to promote reduce unwanted to behavior is to respond by restating the expectation of the desired behavior and to provide frequent opportunities for positive practice (Simonsen et al., 2008). Responding to behavior in the absence of instruction deprives students of understanding the desired behavior and developing the behavioral 
skills to consistently meet classroom expectations. It was hypothesized that teachers in this study may implicitly reprimand African American students more that students from other races, contributing to a coercive interaction cycle. In addition, the researchers anticipated that teachers may respond to unwanted student behavior without restating the behavior expectation and providing opportunities to practice. Thus, the elements of responding to unwanted behavior with an instructional approach was a critical component to this intervention.

Use disaggregated data by race. Researchers have suggested that disaggregated data is critical for understanding and improving racial inequities in school discipline (McIntosh, Ellwood, et al., 2018), but none have looked at disaggregating praise and reprimand data by race thus far. Providing teachers visual feedback on their implementation of intervention components has been supported to improve the implementation of effective classroom management (MacSuga \& Simonsen, 2011; Reinke, Lewis-Palmer, \& Merrell, 2008). It is hypothesized in this study that visual performance feedback on discrepancies between rates of praise and rates of reprimands for African American students will help to bring awareness to potential implicit biases and help to spur behavioral change to increase praise and decrease reprimands for African American students.

Provide coaching to support intervention implementation. Effective coaching can lead to enhanced intervention implementation. The Classroom Check-up (CCU) is one coaching model that has been tremendously effective at helping teachers become more effective in implementing proactive classroom management strategies (Reinke, Herman, \& Sprick, 2011; Reinke et al., 2008). CCU consists of five steps: (a) initial rapport 
building through a teacher intake interview, (b) data collection via direct observation, (c) feedback to the teacher regarding areas of relative strength and weakness, (d) collaborative goal setting and action planning, and (e) implementation with progress monitoring and follow-up feedback. CCU is also predicated on the coach's use of motivational interviewing techniques (Miller \& Rollnick, 2002) to promote teacher engagement and to improve acceptance, effectiveness, and contextual fit of intervention implementation. Due to the sensitivity and complexity of implementing an intervention aimed at improving rates of praise and reducing rates of reprimands for African American students, this study used an adapted version of the CCU elements to enhance intervention implementation in this study.

\section{Present Study}

The objective of this dissertation was to test the effect of the classroom intervention on teacher interactions with students.

\section{Research Questions}

The study examined the following primary (experimental) research questions:

1. Is there a functional relation between the implementation of a classroom intervention and an increase in teacher use of praise for African American students?

2. Is there a functional relation between the implementation of a classroom intervention and a decrease in teacher use of reprimands for African American students?

In addition, the proposed research addressed the following secondary (descriptive) research questions: 
3. Is the implementation of the multifaceted classroom intervention associated with equitable ODR outcomes for African American students?

4. To what extent do teachers find the multifaceted classroom intervention socially valid? 


\section{CHAPTER II}

\section{METHOD}

\section{Setting}

Two schools in an urban district located in the Pacific Northwest were approached to be sources for participating teachers and classrooms. The district had partnered with the second author on school-wide PBIS implementation and equity in school discipline, and administrators from both schools agreed to participate. Demographic data were obtained through each school's most current state report card. Acadia school was a K-8 school with an enrollment of 451 students (White $=55 \%$, African American $=17 \%$, Hispanic $/$ Latinx $=13 \%$, Asian $=1 \%$ ), and $29 \%$ of these students received free or reduced-price meals. Maple Park was a K-5 school with an enrollment of 334 students (African American $=42 \%$, White $=23 \%$, Hispanic $/$ Latinx $=23 \%$, Multi-Racial $=8 \%$, Asian $=1 \%$, Hawaiian $/$ Pacific Islander $=1 \%$, Native American/Alaska Native $=1 \%$, and $100 \%$ of the students in this school received free or reduced-price meals.

\section{Participants}

School administrators nominated and obtained consent from teachers who they thought would be good candidates to participate in the study and whose classroom racial diversity was adequate to examine racial equity (i.e., between $25 \%$ and $75 \%$ of students in the class were African American). The 25\% to 75\% African American criterion was used to ensure sufficient diversity was present to identify impacts of the intervention on racial equity. Teachers were then contacted by the primary researcher, who explained what participation of the study entailed. 
Participants for this study included four general education classroom teachers, two from each school. Sofia and Martina (pseudonyms used throughout) were recruited from Maple Park and Alma and Orien were recruited from Acadia. Sofia was a fifth-year teacher, who was Pacific Islander/Asian and female. She taught a classroom of 21 second-grade students (African American =12, Other =9). Martina was a 17th-year classroom teacher who was Hispanic/Latina and female. She had 15 kindergarten students (African American =6, Other =9). Alma was a third-year teacher who was Hispanic/Latina and female. She taught fifth grade and had a classroom of 28 total students (African American = 5, Other = 23). Orien was a first-year teacher who was White and male. He taught a seventh-grade class of 21 students (African American =6, Other $=15)$.

\section{Measures}

Observation of teacher behavior. The researcher and a trained observer collected frequency counts of (a) behavior-specific praise (BSP), (b) general praise (GP), (c) explicit reprimands (ExR), and (d) harsh reprimands (HR), using the operational definitions of teacher behaviors from the Brief Classroom Interaction Observation Revised (BCIO-R) measure (Reinke, Stormont, Herman, Wachsmuth, \& Newcomer, 2015). These variables were selected based on their significant impact on student outcomes identified in previous research.

Separate frequency counts were tallied based on student race. Observers determined student race as either African American or All Other (i.e., not African American) through an initial conference with the teacher where each participant identified the African American students in their class. Additionally, the primary 
researcher and trained observer identified the students in each racial category, who were present before each observational session.

Teachers were observed during 20-minute daily sessions during the time of day when unwanted behavior incidents were most likely to occur. Teachers self-identified the time of day that was most problematic during the initial intake interviews. Direct observation occurred at the same time of day throughout the study for each teacher, and the data were disaggregated by student race (i.e., African American vs. All Other). Observations for Alma's classroom occurred from 9:00 am to 9:20 am during Math instruction, Orien's observations occurred from 9:50 am to 10:10 am during English Language Arts instruction, Sofia's observations occurred from 1:00 pm to 1:20 pm during Math instruction, and Martina's observations occurred from 2:00 pm to 2:20 pm during Math instruction. The type of instruction (e.g., independent seat work, whole group, cooperative group work) varied within and across observational periods.

Combined praise (i.e., BSP and GP) and reprimand (i.e., ExR and HR) rates were calculated by dividing the frequency of praise for a specified sample (i.e., African American or All Other) by the number of students in the sample present during that day's observational session. For example, if five African American students received a total of 10 reprimands during a 20 -min observational session, the reprimand rate would be 2.0 . Converting raw frequencies to rate measures based on the number of students allowed for a more accurate representation of equity across racial groups.

Behavior-specific praise (BSP). The operational definition for BSP was as follows: verbal statements that indicate approval and name a specific behavior. This included descriptors related to emotional regulation or social skills (e.g., friendly, kind, 
respectful, honest, responsible). Additionally, praise included referring to behaviors that students have learned (e.g., body basics). Examples of BSP included, "Thank you for sitting quietly" and "Maria is showing me she is ready with her eyes on me". Nonexamples of BSP included general praise statements (e.g., "Nice job!") and statements regarding correct academic answers without statements of approval (e.g., "Yes, $2+2$ is 4").

General praise (GP). The operational definition for GP was as follows: verbal statements or gestures that indicate approval and do not name a specific behavior (e.g. "Kiss your brain," "Give me a bam," "Good job," teacher giving out reinforcement tokens, high five to student, clapping, thumbs up).

Explicit reprimand (ER). The operational definition for ER was as follows: verbal comments or gestures by teacher to indicate disapproval of behavior; reprimand is concise (brief) in a normal speaking tone. ERs included error corrections, where a teacher responds to a social behavior error with the correct response provided by the teacher (e.g., "Tim you need to put your book away and begin working."). ER was only for social behaviors and not for academic behaviors. ER depended on what a student or group of students were doing prior to the reprimand. Examples of ER included, student is not paying attention and the teacher says, "You need to follow along in the book", or the entire class was too loud, and the teacher says, "I need your eyes up here, before I continue.” Non-examples of ER included harsh reprimands (see below), stating expectations before activities, and corrections for academic errors (e.g., "That word is renaissance"). 
Harsh reprimand (HR). The operational definition for HR was as follows: verbal comments or gestures that indicate disapproval of behavior using a voice louder than typical for setting, a harsh, critical, or sarcastic tone, or an explicit reprimand lasting longer than 30 seconds. Examples of HR included, a student not paying attention, and the teacher says, "You are never in the right place, we are on page 97," or the entire class misbehaved the day before for a substitute teacher and the teacher addresses the class which lasts longer than 30 seconds. Non-examples of HR included ER statements and gestures, and corrections for academic errors.

Office Discipline Referrals (ODRs). Both schools, participating in this study, used the School-Wide Information System (SWIS; May et al., 2013) to collect ODRs during the 2017-2018 academic school year. ODRs are a valid and reliable tool for analyzing student behavior (Irvin, Tobin, Sprague, Sugai, \& Vincent, 2004). Descriptive ODR rates were analyzed before and after intervention to determine the potential impact of the intervention on exclusionary discipline.

\section{Culturally Responsive - Classroom Observation Checklist (CR-COC). In}

addition to frequency counts of praise and reprimands, a researcher-developed observation checklist (Appendix A) was completed by observers during each session across all phases (i.e., baseline and intervention) to assess qualitative elements of the intervention. The CR-COC indicated the presence of intervention defining elements, such as teaching expectations and analysis of the quality of praise and reprimands to guide intervention selection and formative assessment of intervention implementation across phases. Data collectors used a rubric to guide ratings and to clarify intervention elements for teachers. 
Primary Intervention Rating Scale (PIRS). The PIRS was administered to teachers post intervention, asking about their perceptions of (a) the acceptability, (b) the effectiveness, and (c) the contextual fit of the intervention. This scale (Appendix B) was used as a descriptive measure of social validity (Lane, Robertson, \& Wehby, 2002). The PIRS is a one-factor measure with strong internal consistency (.97 or higher) normed for grades K-12, and high ratings on the PIRS are predictive of higher levels of treatment fidelity (Lane et al., 2009).

Coaching logs. The primary researcher served as the coach for the teachers in this study. He kept logs by the minute and appropriately coded each coaching activity completed during both the baseline and intervention phases and minutes were entered into an Excel spreadsheet (Appendix C). These logs were used to document the cost in time of implementing the intervention and to provide an indication of the approximate time it might take for coaches to complete each aspect of the intervention. The primary researcher completed all features of the teacher intake interview, action planning meeting, and follow-up interviews, as evidenced by field notes and completed structured interview forms. Additionally, the primary researcher provided visual performance feedback during the intervention phase by sending teachers their updated graphs, scanned observation forms, and the classroom observation checklist rubric after $100 \%$ of observation sessions, as evidenced by emails sent to teachers.

Inter-Observer Agreement (IOA). Data collectors were provided written definitions of each target behavior (i.e., BSP, GP, ExR, and HR) and sufficient examples and non-examples of each behavior. The primary researcher met with the additional data collector prior to the study and established reliability through direct observations of non- 
target classrooms in a neighboring school district. Each observer was required to obtain $85 \%$ reliability agreement for all variables before collecting data for the study.

\section{Procedure}

Experimental design. A concurrent multiple-baseline, single-case design across four teachers was used in this study. It consisted of two phases (baseline and intervention). The start order in which teachers received intervention was randomly assigned using a random number generator. To meet WWC single-case design standards without reservations, the design allowed for at least three demonstrations of effect, at three different points in time, and each participant's baseline and intervention phases had at least five data points (Kratochwill et al., 2013). The intervention was introduced in staggered fashion in the random order after at least five data points and stability in baseline responding.

Intake meeting. The coach held an intake meeting (Appendix D) with each teacher to review consent procedures and ask the teacher about their (a) experience, (b) values, (c) management style, (d) ideal classroom, and (e) past coaching experiences. The primary researcher used motivational interviewing techniques (a core component of $\mathrm{CCU})$ to build rapport with each teacher, better understand their classroom ecology, and establish potential reasons for behavior change in the future (Reinke et al., 2008). One of the motivational interviewing strategies used during this interview to build rapport was an adapted values card sort activity, where each participant was asked to sort value statements which were personal (e.g., "Taking care of my family”), professional (e.g., "Having a safe classroom), and equity (e.g., "Dismantling Institutional Racism”) focused written on cards into categories of "Very Important," "Important," and "Less Important" 
(cards can be obtained from the researcher upon request). After cards were sorted, the researcher had each participant pick their three most important values from the "Very Important" list and reflect on why they chose those values. Additionally, during this initial meeting, the coach and the teacher identified the best time to conduct classroom observations (i.e., time where unwanted behavior was most likely to occur) to obtain baseline data.

Baseline phase. Teachers were urged to provide instruction as usual during baseline. Observers collected frequency data of praise and reprimands, in addition to qualitative measures of the delivery of these behaviors and teaching culturally responsive expectations. Observations were 20 -min each and occurred during the same times of day as the intervention phase. Instruction was similar for each participant across phases.

Intervention phase. The intervention implemented in this study relied on five defining elements: (a) define and teach desired behavior with cultural considerations, (b) increase acknowledgement for African American students, (c) respond to unwanted behavior using an instructional approach, (d) use disaggregated data by race to guide intervention implementation, and (e) provide coaching to enhance intervention implementation. The implementation of this intervention was supported through a series of strategies described here.

Classroom Check-Up (CCU). An adapted CCU coaching model was used to support intervention implementation throughout the intervention phase. The CCU has been used effectively to change teacher behavior (i.e., rates of praise and reprimands) in previous research (Reinke et al., 2008). The coaching model consisted of (a) an initial motivational interview meeting (described in Intake meeting), (b) data collection on 
praise and reprimand rates, as well as other relevant strategies listed on the CR-COC, (c) an action planning meeting where baseline data were reviewed, teacher strengths and weaknesses were discussed, and a goal and an action plan was put in place, (d) performance feedback was provided during each observational session, and (d) a followup meeting was held to review progress toward goals and make adjustments, as needed.

There were two significant adaptations made to the CCU model that should be noted. First, the researcher reviewed the data from the CR-COC with the teacher, as opposed to the classroom management forms used in previous research (Reinke et al., 2008). Second, praise and reprimand data were presented as disaggregated data by student race (i.e., African American and All Other) to depict differences between racial groups. Otherwise, the format of the $\mathrm{CCU}$ remained the same with the key coaching behaviors of motivational interviewing and visual performance feedback.

Action planning meeting. The primary researcher held an individual action planning meeting (Appendix F) with each teacher at the end of each baseline phase, before the implementation of the intervention components. To prepare for this meeting, the primary researcher compiled the baseline observational data into visual formats. The frequency data of praise and reprimands were graphed separately by race of student as ratios (praise:reprimands for African American students and praise:reprimands for All Other). The reason for choosing this method of presentation was two-fold. First, most teachers are familiar with the "magic ratio" of praise statements to corrections, thus it was hypothesized that this format would be easier to understand than a rate-based representation. Second, the primary researcher wanted to draw attention to the relationship between praise and reprimands and avoid misrules of (a) providing frivolous 
praise or (b) avoiding providing reprimands when necessary. Separation on the graph between African American and All Other students would indicate disproportionality in praise:corrections ratios.

The second process of preparing for the action-planning meeting was to compile the CR-COC data into a summary format (Appendix E). The coach reviewed the observational data and determined areas of strength and areas that needed attention for each participant. Areas of strength and areas that needed attention were decided based on the consistency of implementation for each individual teacher. The primary researcher reviewed the data and made a subjective judgement about the overall consistency of implementation for each item. These judgments were then tested for accuracy by asking the teacher if the data seemed consistent with their perceptions during the data review portion of the action-planning meeting.

The action-planning meeting consisted of four discrete steps presented in a guided format. The meeting began with a review of the purpose of the study and rationale as to why measuring praise and reprimands are important for improving student outcomes. Teachers were given documents describing (a) what behavior specific praise is, (b) why it is an important strategy to implement, and (c) tips to help make implementation easier. Following this brief review, the prepared data were reviewed. The coach explained the data to the teacher using a straightforward and neutral tone. Teachers were encouraged to ask clarifying questions and to provide their perspective about if the data seemed to be an accurate representation of what was observed in their classroom. After the data were reviewed and discussed, the coach and the teacher established a goal based on the data. Each teacher in this study had a goal of achieving a praise to reprimand ratio of over 1.0, 
indicating students were receiving more praise than reprimands during the observational period. Praise:reprimand ratios were determined by dividing the frequency of praise statements observed by the frequency of reprimands observed.

The coach used motivational interviewing techniques to establish the importance of achieving this goal and to identify any potential barriers that may get in the way. Teachers rated the goal of having a praise to reprimand ratio relatively high, with all participants providing ratings of 8 or higher (10 being most important). Teachers also identified any barriers that could get in the way of achieving this goal and voiced ways the coach could help overcome these barriers. To overcome uncertainty, one action the coach took was to provide each teacher with a list of praise statements (e.g., Wow, look how big and tall ___ is sitting, Great! You said all the sounds correctly, ___.) and a video of how praise could be implemented in the classroom setting.

To ensure praise was genuine, specific, and targeted, teachers were encouraged by the coach to praise behaviors that were inconsistent, uncommon, and behavior specific. They were also guided to provide praise for the specific behaviors they wanted to see more of. The theory behind this practice was to ensure reinforcement was being applied in a way that maximized the probability of meaningful behavior change.

The meeting concluded with establishing actionable items with established timelines to enhance the clarity in expected behavior for both the teacher and the coach. Elements of the intervention package were selected based on baseline data. These elements are described below.

Visual performance feedback. In this study, the primary researcher emailed graphs of disaggregated praise:reprimand ratios and recommendations for improvement 
after each observation session. The researcher used a standard email format consisting of one to three behaviors that were noticed during the observational session (e.g., "You used the praise-around strategy often.") and one to three recommendations for improvement (e.g., "Continue to give more praise to students who may be struggling to follow directions."). The email included attachments of scanned copies of the raw observation data, the current action plan, and the CR-COC rubric for reference.

Student personal matrix. Following the action-planning meeting, teachers implemented an activity where their students were asked to complete a personal matrix (Appendix F) (Leverson et al., 2016). Students identified what classroom expectations looked like in their homes and in their neighborhoods. For example, respect might look like raising a hand to answer a question in the classroom, but may look like helping mom with the dishes at home. Teachers used the information they gathered from this activity to reflect on their classroom expectations and how they may be similar or different from each individual student's life outside of school. Teachers were encouraged to clarify any significant differences between home and school, and to adjust their expectations, if needed, to better align with student's background knowledge and cultural values.

Praise preference assessment. Additionally, teachers conducted a praise preference assessment to better understand the type of reinforcement that was most motivating for each individual student (e.g., PBIS token economy, edible, social reinforcement; Appendix G). The information gathered during the praise preference assessment was used to shape existing classroom acknowledgement systems to provide more individualized reinforcement for desired behavior. Teachers were encouraged to strategically tailor their reinforcement to meet individual student needs and to increase 
the use of strategies that were highly preferred. For example, teachers increased their use of PBIS tickets or goldfish crackers to reinforce desired behavior based on the results of this assessment.

The personal matrix and praise preference activities were adapted for each individual classroom setting. Teachers were encouraged to use the basic format of each activity, but to adjust it to improve contextual fit for their classroom. Orien ( $7^{\text {th }}$ grade) and Alma $\left(5^{\text {th }}\right.$ grade $)$ chose to have students complete both activities independently during class. Sofia ( $2^{\text {nd }}$ grade) chose to do the activities in a guided small group format, and Martina (Kindergarten) chose to do the activities in an individual interview format, where the primary researcher and trained data collector pulled each individual student to ask them about the expectations at home and to identify their preference for praise. Teachers were encouraged to reflect on these data to shape classroom management strategies in ways that were more consistent with student needs.

Follow-up meeting. The coach and the teacher had one follow-up meeting within two weeks after initial implementation (Appendix H). The structure of this meeting was to review outcome and fidelity data, the previous action plan, and to create new action items, as needed. Action plan revision was based on consistent achievement of previously established goals. Based on performance, additional action items were not needed for Sofia, Martina, and Orien. The coach worked with Alma to revise the original action plan and included the items of providing a script for teaching expectations and a script for responding to unwanted behavior. The previously established goal of a praise:reprimand ratio above one stayed the same. 


\section{Data Analysis}

Systematic visual analysis was conducted to determine a functional relation between the intervention and outcome data. Data were analyzed through inspection of

level, trend, and variability for each phase and by each participant. Then, vertical analysis was conducted to determine the effect of the intervention across participants.

In addition to visual analysis, we used a mean difference statistic (Hedge's $g$ ) designed for single-case research to determine the effect of the intervention on the outcomes of teacher praise and reprimands for African American students. This statistic is equivalent to the usual $d$ statistic in between-groups designs and is appropriate for use in single-case multiple baseline designs (Hedges, Pustejovsky, \& Shadish, 2013). Criteria for determining the size of the effect of the intervention on specific target outcome variables (i.e., teacher praise and reprimand rates) was determined as follows, small $g=$ 0.20 , medium $g=0.50$, large $g=0.80$ (Cohen, 1977).

Results from the PIRS assessment were analyzed and reported descriptively. The researcher noted responses for all four classroom teachers and displayed the data for each item as percentages (i.e., each teacher rating $=25 \%$ of the total). 


\section{CHAPTER III}

\section{RESULTS}

Our primary anticipated outcome was a reduction in reprimands and an increase in praise rates for all students, with more equitable distributions reprimands and praise for African American students compared to all other students. Figures 3, 4 and 5 show the results of the study, consistent with the a priori hypothesis.

Figure 3. Ratio of Teacher Praise to Reprimands By Race

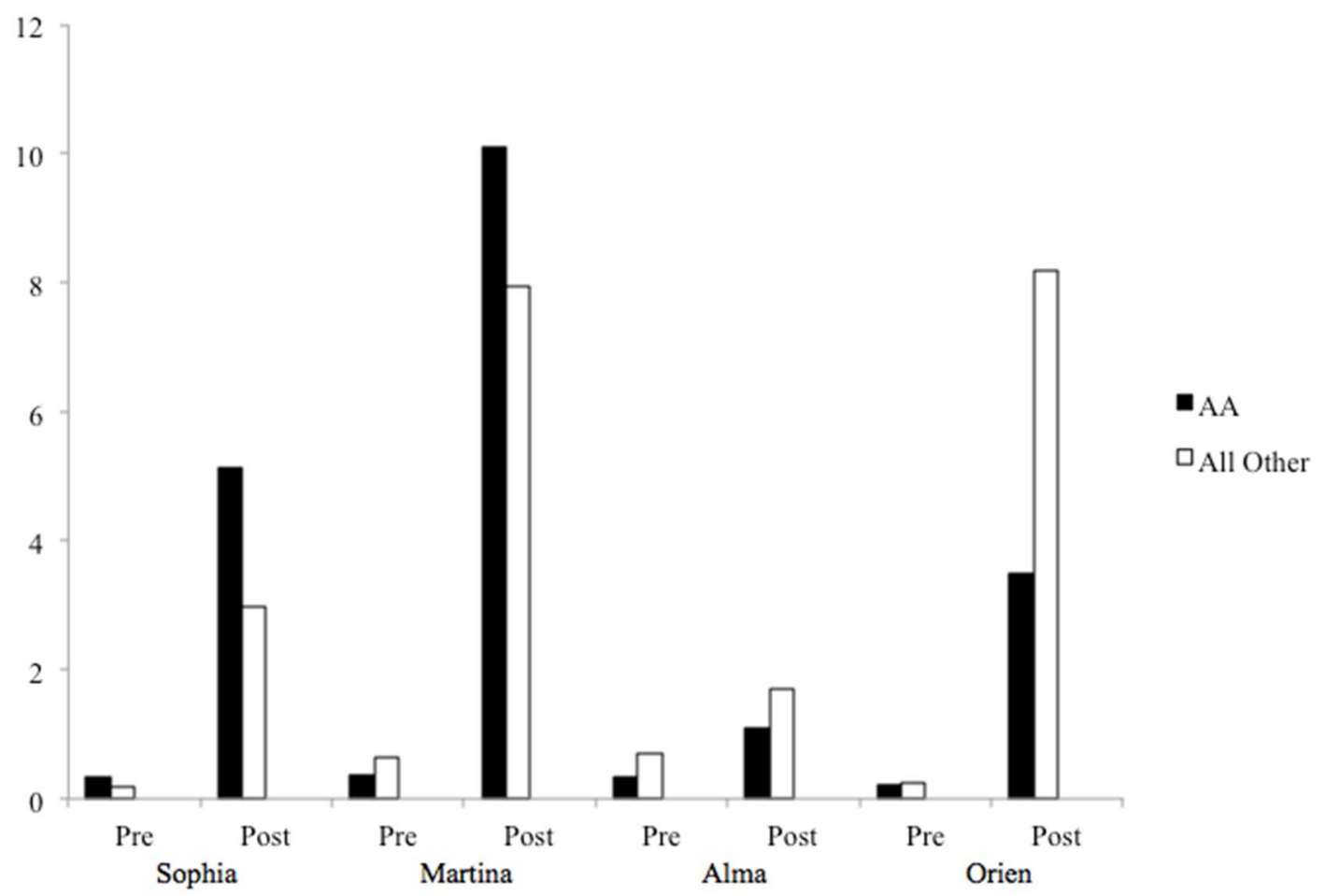

Praise to reprimand ratios by racial group (i.e., AA = African American and All Other) across four classrooms before (Pre) and after (Post) intervention. 
Figure 4. Frequency Rates for Teacher Praise Per Student Across Classrooms

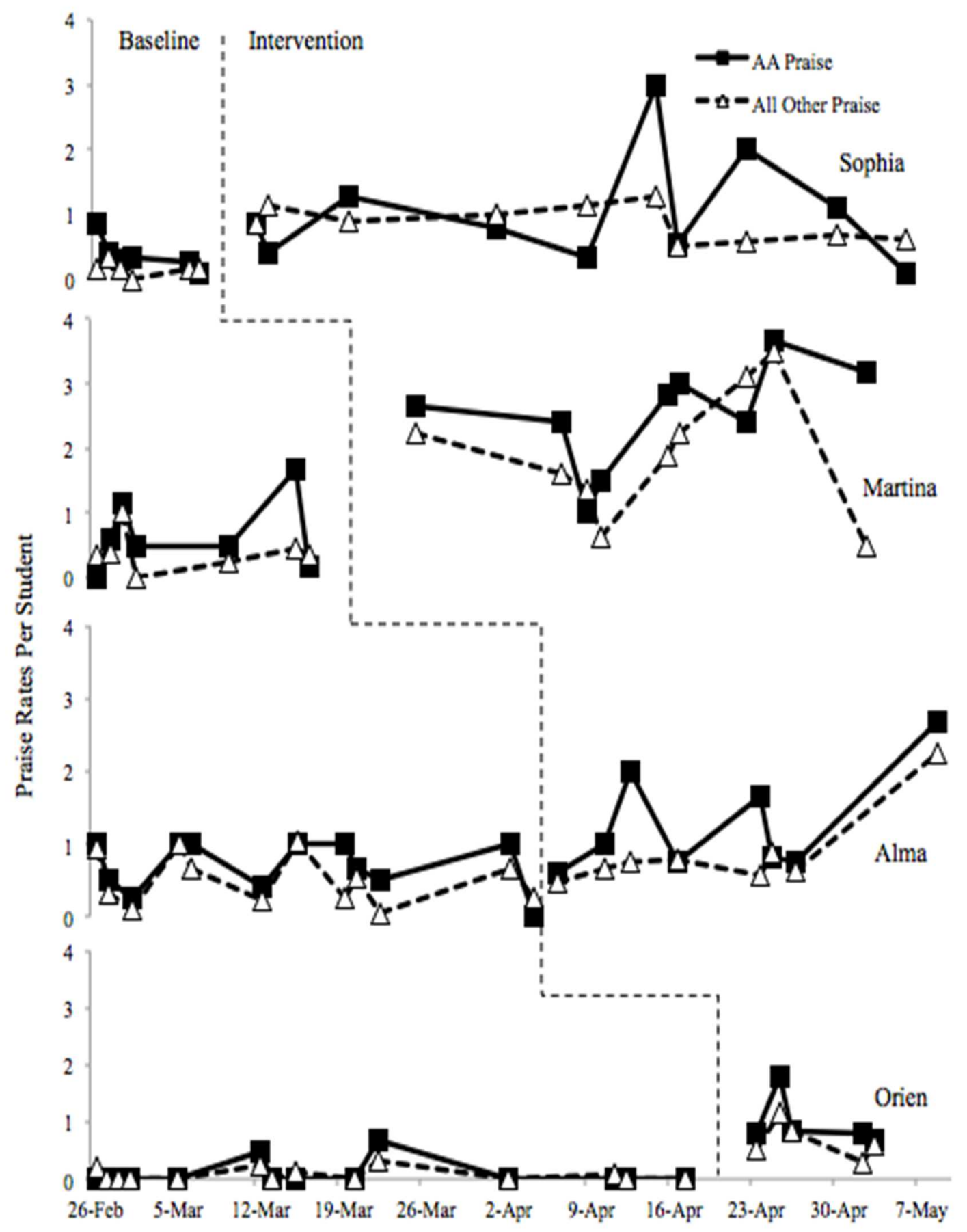

Teacher praise rates per student across four classrooms for African American (AA) students and students who are not African American (All other). 
Figure 5. Frequency Rates for Teacher Reprimands Per Student Across Classrooms

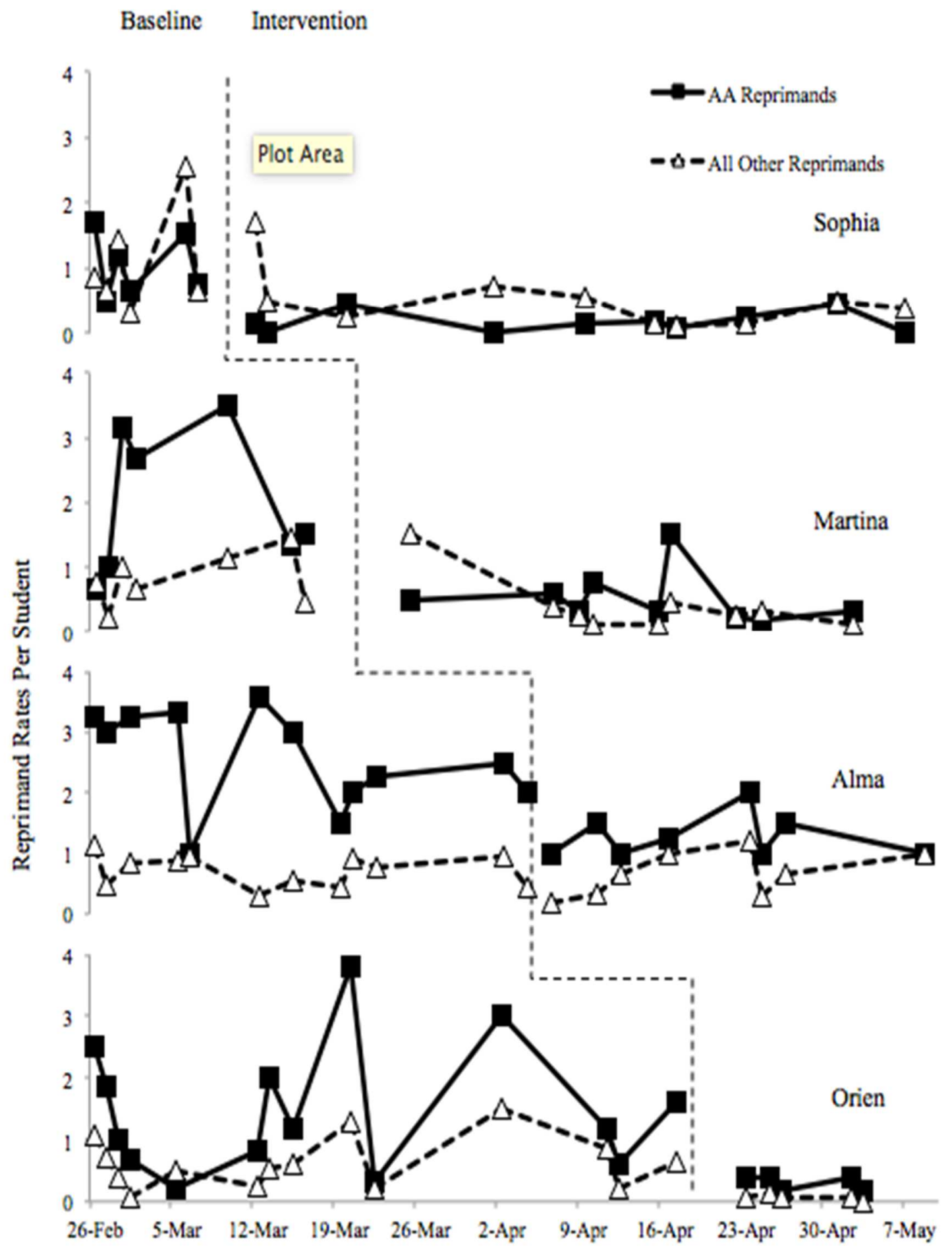

Teacher reprimand rates per student across four classrooms for African American (AA) students and students who are not African American (All other). 


\section{Inter-Observer Agreement (IOA)}

IOA was calculated using the total count IOA method for each direct observation measure. Total count IOA was calculated by dividing the smaller total count observed (from one observer, relative to the other) by the larger total count (from the other observer). IOA data were collected for $38 \%$ of all sessions across teachers and phases (Range $29-60 \%$ ). Average IOA was 90\% for Praise (Range $76-100 \%$ ) and $94 \%$ for Reprimands (Range 75-100\%). This level of agreement is consistent with methodological WWC SCD guidelines that specify IOA needing to be collected for at least $20 \%$ of sessions across participants and phases with reliability above at or above $80 \%$ (Kratochwill et al., 2013). Observers had a conversation and came to a consensus on operational definitions for IOA that fell below $80 \%$ during any single observation period to improve IOA for subsequent observations.

\section{Office Discipline Referrals (ODRs)}

During the 2017-2018 school year, participating teachers had low rates of ODRs. Sophia and Orien issued two referrals, Marina issued one referral, and Alma issued zero referrals to African American students in the seven months before intervention. Teachers did not issue an ODR to students from All Other racial groups. Additionally, teachers did not issue an ODR to any student (i.e., African American and All Other) starting with and three months following intervention.

\section{Culturally Responsive - Classroom Observation Checklist (CR-COC)}

Average implementation percentages of CR-COC elements were calculated for each intervention element (See Table 1). Fidelity was rated on as "Never" (0), "Inconsistent" (1), and "Consistent" (2) for each observational session across both 
baseline and intervention phases. Each participant increased their implementation for each intervention element during the intervention phase of the study. During baseline, Sophia was the only participant with an average rating over $80 \%$ for teaching expectations. During intervention, all participants, except Alma (60\%), had average ratings above $80 \%$ for teaching expectations. Average praise ratings were below $80 \%$ for all participants during baseline and above $80 \%$ during intervention, except for Alma (45\%). Average reprimand ratings were above $80 \%$ for all participants, except Alma (52\%) and Orien (78\%), during baseline and over $80 \%$ for all participants during intervention, except Alma (67\%).

Table 1

Average Implementation Across Phases

\begin{tabular}{lccccccccc}
\hline & \multicolumn{3}{c}{ Teaching Expectations } & \multicolumn{3}{c}{ Praise } & & & \multicolumn{2}{c}{ Reprimands } \\
& Baseline & Intervention & Difference & Baseline & Intervention & Difference & Baseline & Intervention & Difference \\
\hline Sophia & $89 \%$ & $95 \%$ & $+6 \%$ & $52 \%$ & $89 \%$ & $+37 \%$ & $90 \%$ & $94 \%$ & $+4 \%$ \\
Martina & $73 \%$ & $99 \%$ & $+26 \%$ & $42 \%$ & $96 \%$ & $+54 \%$ & $86 \%$ & $95 \%$ & $+9 \%$ \\
Alma & $44 \%$ & $60 \%$ & $+16 \%$ & $39 \%$ & $45 \%$ & $+6 \%$ & $52 \%$ & $67 \%$ & $+15 \%$ \\
Orien & $39 \%$ & $94 \%$ & $+55 \%$ & $33 \%$ & $92 \%$ & $+59 \%$ & $78 \%$ & $95 \%$ & $+17 \%$ \\
\hline
\end{tabular}

\section{Coaching Logs}

Across participants the primary researcher spent a total of 47 hours and 58 min (2,878 min) engaging in coaching activities. A breakdown of the time spent for each coaching activity is as follows: Fifty-two percent $(1,500 \mathrm{~min})$ collecting data via direct observation, 19\% (555 min) providing feedback via face-to-face or over email, 10\% (295 min) interviewing teachers, 8\% (240 $\mathrm{min})$ action planning, 5\% (143 min) scheduling, 4\% 
(115 min) preparing for action-planning and follow-up meetings, and 3\% (90 min) preparing materials after action-planning and follow-up meetings.

\section{Praise}

Sofia. In baseline, Sofia's rates of praise were consistently low and stable across both groups (African American $M=0.37$ per student, All Other $M=0.15$ ), with a slight decreasing trend for African American students. There were few differences in praise by race. Upon intervention, there was a strong immediacy of effect for both groups, with an increase in level (African American $M=1.04$ per student, All Other $M=0.86$ ) and higher, but more variable, praise rates for African American students.

Martina. In baseline, Martina's rates of praise were moderate with slight variability across both groups (African American $M=0.66$ per student, All Other $M=$ 0.39), with a stable trend for both African American and other students. On average, African American students received more praise than All Other students. Upon intervention, there was a strong immediacy of effect for both groups, with an increase in level (African American $M=2.73$ per student, All Other $M=1.98$ ) and higher praise rates for African American students. Praise for African American students also showed an increasing trend throughout the intervention phase.

Alma. In baseline, Alma's rates of praise were moderate with slight variability across both groups (African American $M=0.69$ per student, All Other $M=0.50$ ), and a stable trend for both African American and All Other students. There were few differences in praise by race. Upon intervention, there was a no immediacy of effect for either group, but there was an increase in trend and a slight increase in variability throughout the intervention phase, resulting in increased in levels of praise for both 
groups (African American $M=1.28$ per student, All Other $M=0.87$ ) with a stronger effect for African American students.

Orien. In baseline, Orien's rates of praise were low and stable, with a stable trend, across both groups (African American $M=0.08$ per student, All Other $M=0.07$ ). There were few differences in praise by race. Upon intervention, there was an immediate of effect for both groups, resulting in increased in levels of praise for both groups, (African American $M=0.98$ per student, All Other $M=0.69$ ) with a slightly stronger effect for African American students.

Vertical analysis. Data showed an immediate positive effect in praise rates across three of the four participants (Sophia, Marina, and Orien). When the intervention was introduced, the effect of the intervention on increasing praise for both racial groups was seen for the target teacher, but praise rates for other teachers in baseline remained low. This data demonstrates the immediate effect of the intervention at three different points in time for both racial groups, supporting a functional relation between the implementation of the intervention and increased praise rates.

\section{Reprimands}

Sofia. In baseline, Sofia's rates of reprimands were moderate to high with substantial variability and a stable trend for both groups (African American $M=1.06$ per student, All Other $M=1.09)$. There was little differentiation in reprimands by race. Upon intervention, there was a strong immediacy of effect for African American students and no immediate effect for students from other races, both groups showed a decrease in level (African American $M=0.18$ per student, All Other $M=0.50$ ) with a stronger effect for 
African American students. Both groups showed less variability and a stable trend across the intervention phase.

Martina. In baseline, Martina's rates of reprimands were high for African American students and moderate to high for other students (African American $M=1.98$ per student, All Other $M=0.81$ ), African American student data had more variability than other student data, and both groups showed a stable trend across the intervention phase. On average, African American students received more reprimands than other students. Upon intervention, there was a strong immediacy of effect in terms of a decrease for African American students and no immediate effect for other students. Both groups showed a significant decrease in level (African American $M=0.49$ per student, All Other $M=0.39$ ) and less variability during intervention. There was a decreasing trend for other students with a stable trend for African American students throughout the intervention phase.

Alma. In baseline, Alma's rates of reprimands were high for African American students and moderate for other students (African American $M=2.56$ per student, All Other $M=0.72$ ), with a stable trend for both groups. African American student data showed more variability and African American students received more reprimands than other students during baseline. Upon intervention, there was an immediate effect for both groups, with a substantial change in level for the African American group only (African American $M=1.28$ per student, All Other $M=0.66$ ). There was a stable trend for African American students and a slightly increasing trend for All Other students. African American student data also showed less variability during intervention and reprimands were more equitable across groups, compared to baseline. 
Orien. In baseline, Orien's rates of reprimands were high for African American students and moderate to high for other students (African American $M=1.48$ per student, All Other $M=0.63)$. African American students received more reprimands on average than All Other students during baseline. Both groups had variable data, with a stable trend. Upon intervention, there was an immediate effect for both groups, resulting in decreased levels of reprimands for both groups, (African American $M=0.31$ per student, All Other $M=0.07)$. Data during intervention was stable with a stable trend. Additionally, reprimand rates were more equitable across racial groups during the intervention phase, when compared to baseline.

Vertical analysis. In addition to examining the effect of the intervention for individual teachers, it is important to compare the effects of the intervention across participants. Data showed an immediate decrease in reprimand rates for African American students when each teacher received the intervention, while rates of reprimands for the other participants still in baseline remained high. This effect was obtained across all participants in the study, indicating a functional relation between intervention implementation and decreased rates of reprimands for African American students.

Second, reprimand differences for African American students compared to other students remained discrepant throughout the baseline phase for Martina, Alma, and Orien, but not for Sophia. When the intervention was introduced, there was an immediate effect resulting in little differentiation between groups for the target teacher, but not for the remaining teachers in baseline, indicating a lack of contamination between participants and supporting the demonstration of a functional relation between the 
implementation of the intervention and improved equity in reprimands between racial groups.

\section{Data summary}

Data indicated a functional relation between the intervention and an increase in the level of praise for African American students and for All Other students. Based on the results from visual analysis, there were no substantial differences between groups during the intervention phase. The results from statistical analysis also support these claims, as evidenced by large effects from the Hedge's $g$ analysis (African American =1.12, All Other $=1.12$ )

Additionally, data indicated a strong functional relation (i.e., three demonstrations of effect at three different points in time) between the intervention and decrease in reprimands for both groups, with a stronger effect for African American students. Hedge's $g$ results for reprimands were -1.16 for African American students and -0.97 for All Other students, both large effects that supported the results from visual analysis.

\section{Primary Intervention Rating Scale (PIRS)}

The PIRS was administered post-intervention after the study to obtain teacher

feedback about the (a) the acceptability, (b) the effectiveness, and (c) the contextual fit of the intervention. Descriptive results from the PIRS are displayed in Figure 3. Overall, participants in this study felt the intervention was acceptable, effective, and a good fit for their school and classroom setting with all items achieving mean ratings above four (average mean $=5.32)$. 
Figure 5. Primary Intervention Rating Scale (PIRS) Results

\begin{tabular}{|c|c|c|c|c|c|c|}
\hline PIRS Results & $\begin{array}{l}1 \\
\text { Strongly } \\
\text { Disagree }\end{array}$ & $\begin{array}{l}2 \\
\text { Disagree }\end{array}$ & $\begin{array}{l}3 \\
\text { Slightly } \\
\text { Disagree }\end{array}$ & $\begin{array}{l}4 \\
\text { Slightly } \\
\text { Agree }\end{array}$ & $\begin{array}{l}5 \\
\text { Agree }\end{array}$ & $\begin{array}{l}6 \\
\text { Strongly } \\
\text { Agree }\end{array}$ \\
\hline $\begin{array}{l}\text { 1. This would be an acceptable } \\
\text { intervention for the school. }\end{array}$ & & & & & $50 \%$ & $50 \%$ \\
\hline $\begin{array}{l}\text { 2. Most teachers would find this } \\
\text { intervention appropriate }\end{array}$ & & & & & $100 \%$ & \\
\hline $\begin{array}{l}3 \text { This intervention should prove } \\
\text { effective in meeting the purposes. }\end{array}$ & & & & & $100 \%$ & \\
\hline $\begin{array}{l}\text { 4. I would suggest the use of this } \\
\text { intervention to other teachers. }\end{array}$ & & & & & $50 \%$ & $50 \%$ \\
\hline $\begin{array}{l}\text { 5. This intervention is appropriate to } \\
\text { meet the school's needs and } \\
\text { mission. }\end{array}$ & & & & $25 \%$ & $50 \%$ & $25 \%$ \\
\hline $\begin{array}{l}\text { 6. Most teachers would find this } \\
\text { intervention suitable for the } \\
\text { described purposes and mission. }\end{array}$ & & & & $25 \%$ & $50 \%$ & $25 \%$ \\
\hline $\begin{array}{l}\text { 7. I would be willing to use this } \\
\text { intervention in the school setting. }\end{array}$ & & & & & & $100 \%$ \\
\hline $\begin{array}{l}\text { 8. This intervention would not result } \\
\text { in negative side-effects for the } \\
\text { students. }\end{array}$ & & & & & $25 \%$ & $75 \%$ \\
\hline $\begin{array}{l}\text { 9. This intervention would be } \\
\text { appropriate for a variety of students. }\end{array}$ & & & & & $25 \%$ & $75 \%$ \\
\hline $\begin{array}{l}\text { 10. This intervention is consistent } \\
\text { with those I have used in school } \\
\text { settings. }\end{array}$ & & & & $25 \%$ & $75 \%$ & \\
\hline $\begin{array}{l}\text { 11. This intervention is a fair way to } \\
\text { fulfill the intervention purposes. }\end{array}$ & & & & & $100 \%$ & \\
\hline $\begin{array}{l}\text { 12. This intervention plan is } \\
\text { reasonable to meet the stated } \\
\text { purposes. }\end{array}$ & & & & & $75 \%$ & $25 \%$ \\
\hline $\begin{array}{l}\text { 13. I like the procedures used in this } \\
\text { intervention. }\end{array}$ & & & & & $75 \%$ & $25 \%$ \\
\hline $\begin{array}{l}\text { 14. This intervention is a good way } \\
\text { to meet the specified purpose. }\end{array}$ & & & & & $75 \%$ & $25 \%$ \\
\hline $\begin{array}{l}15 . \text { The monitoring procedures are } \\
\text { manageable. }\end{array}$ & & & & & $75 \%$ & $25 \%$ \\
\hline $\begin{array}{l}\text { 16. The monitoring procedures will } \\
\text { give the necessary information to } \\
\text { evaluate the plan. }\end{array}$ & & & & & $75 \%$ & $25 \%$ \\
\hline $\begin{array}{l}\text { 17. Overall, this intervention would } \\
\text { be beneficial for elementary/K-8 } \\
\text { students. }\end{array}$ & & & & & & $100 \%$ \\
\hline
\end{tabular}

Descriptive analysis of acceptability, effectiveness, and contextual fit using the PIRS. 


\section{CHAPTER IV}

\section{GENERAL DISCUSSION}

The first chapter in this dissertation described the pervasive issue of discipline disproportionality in exclusionary discipline for African American students and the logic behind the formulation of the classroom intervention employed in this study. The following chapters described the method and results achieved. This final chapter aims to discuss the results of this study further, revisiting primary aims of the study, describing the limitations and implications of the findings, and presenting some possible future directions for research and practice.

\section{Research Questions 1 and 2}

The study examined the following primary (experimental) research questions:

1. Is there a functional relation between the implementation of a multifaceted classroom intervention and an increase in teacher use of praise for African American students?

2. Is there a functional relation between the implementation of a multifaceted classroom intervention and a decrease in teacher use of reprimands for African American students?

It was hypothesized that disproportionate rates of exclusionary discipline could be the result of disproportionate rates of reprimands and praise for African American students. Findings from this study suggest that all students received low rates of praise, regardless of race, and African American students were more likely to receive higher rates of reprimands when compared to students from other racial backgrounds, for three

out of four teachers (i.e., Martina, Alma, Orien). Additionally, although rates of exclusion 
(i.e., ODR) were low, all instances of exclusionary discipline occurred for African American students. The findings of higher rates of reprimands in correlation with higher rates of exclusionary discipline for African American students is consistent with previous research and potentially supports teacher-student interactions as the basis of contributing to a coercive cycle of inequity for disciplinary discipline (Reinke et al., 2016; Scott et al., 2018).

The implementation of the classroom intervention in this study resulted in a functional decrease in reprimand rates and a functional increase in praise rates for African American students. These students received more praise than reprimands, on average, during the intervention phase. This intervention potentially contributed to changing the dynamic of interactions between teachers and African American students to establish a constructive cycle of increasing equity.

\section{Research Questions 3 and 4}

In addition, the study addressed the following secondary (descriptive) research questions:

3. Is the implementation of the multifaceted classroom intervention associated with equitable ODR outcomes for African American students?

Based on the low rates of ODRs issues by teachers in this study, it is unclear whether the intervention had a positive effect on increasing equity for African American students. It does demonstrate a decrease in exclusionary discipline for African American students.

4. To what extent do teachers find the multifaceted classroom intervention socially valid? 
Teachers implementing the classroom intervention thought it was acceptable, effective, and fit well within their school and classroom contexts. Teachers overwhelmingly rated the intervention high in these three categories. This finding suggests that practitioners could find this intervention useful and feasible to implement in their local settings.

\section{Contributions to the Field}

Recent intervention research in the area of discipline disproportionality has focused largely on exclusionary discipline (Bradshaw et al., 2018, Cook et al., 2018; Gregory et al., 2016), but this study examined the effects of an intervention to reduce precursor behaviors (i.e., teacher-student interactions) that may be contributing to discipline disproportionality. This focus may allow for further development of preventative intervention strategies that are more effective and less resource intensive than intervention focused on solely on behaviors that result in exclusion from the educational environment.

Additionally, the finding that African American students received more negative feedback (i.e., reprimands) than other students is also consistent with previous research (Scott et al., 2018). This might suggest that the critical component to reducing racial disproportionality could be the reduction in negative teacher-student interactions for African American students. Interventions that target minimizing negative teacher-student interactions may have a substantial effect at improving discipline equity.

Finally, this study adds to the growing body of literature of promising classroombased interventions to reduce discipline disproportionality (e.g., Bradshaw et al., 2018, Cook et al., 2018; Gregory et al., 2016). The findings from this study support a 
comprehensive approach rooted in effective coaching strategies, with a reliance on the use of disaggregated data to guide decision-making that has also been supported in previous research (McIntosh, Ellwood, et al., 2018; Reinke et al., 2008). These findings suggest that the classroom may be the primary location for disproportionality and provide some insight into the potential critical components of effective intervention to improve discipline equity.

\section{Limitations and Implications for Future Research}

Although the results of this study are promising, there are some considerable limitations that need to be expressed. First, the dependent variable in this study focused only on teacher behavior and did not measure the impact of the intervention on student behavior. Future research will need to examine these effects to be able to determine if this intervention has a significant impact on more distal measures of discipline disproportionality beyond the descriptive effects on ODRs shown in this study.

Second, the study included a small sample, and more demonstrations of these effects need to be studied to establish this intervention as an evidence-based practice to improve disciplinary equity for African American students. For single-case research, Kratochwill et al. (2013) described the need for findings to be replicated with at least 20 participants, across at least five separate studies, and examined by at least two different research groups to establish a practice as an evidence-based intervention. One single-case study, as reported here, can provide credence and support to the approach used in this study to eliminate discipline disproportionality, but it would be inappropriate to draw firm conclusions from only this study. 
Third, data collectors for this study were not blind to the intervention. Although steps were taken to improve objectivity of the data being collected (i.e., establishing IOA) findings from this study may be influenced by confirmation bias. Future research should examine the replication of these findings with data collectors who are blind to the intervention and the aims of the study.

Fourth, the coaching intervention components were implemented by the primary researcher with significant experience in coaching classroom management. The results of this study need to be replicated with coaches with varying backgrounds and experiences to determine the generalizability of these findings. In addition, future research should examine the feasibility and acceptability of the coaching components by coaches who are internal to the school environment. There may be drastic differences in terms of feasibility and acceptability from coaches within these contexts.

Finally, the intervention focused on individual classroom implementation, independent of larger school systems. Implementation of intervention in isolation, without consideration for systematic support, is limited in its impact and sustainability (Scheirer, 2005; Wiltsey Stirman et al., 2012). Future research and implementation of the classroom intervention will have to be considered within a larger context of system implementation. For example, researchers and practitioners may want to examine how this intervention can be incorporated into school-wide behavior support systems like SWPBIS.

Intervention research to reduce exclusionary discipline disproportionality is in its infancy, but the initial results are promising. Disproportionality is likely to be a multifaceted and complex problem, requiring various interventions depending on 
environmental contexts. This study is merely one supporting branch in a larger body of research. Findings and conclusions made here need to be taken into context within the larger and ever-changing educational context. Future research will want to take steps to further refine the mechanisms and contributing factors that may be contributing to discipline disproportionality.

Researchers will want to examine the validity of the coercive cycle of teacherstudent interactions that may be leading to high rates of exclusion. It would be helpful to know to what extent interactions in the classroom, or perhaps throughout the day, lead to exclusion or increased engagement. It would also be helpful to know to what extent other elements of classroom management and instruction contribute to exclusionary discipline.

\section{Implications for Practice}

Practitioners will want to use their knowledge of their context and their local data to determine potential contributing factors to discipline disproportionality. After identifying the root cause of disproportionality, they may choose to implement the intervention described here or other promising approaches that have been developed. They may want to test varying methods for effectiveness and feasibility, guiding the development of supports that are equitable and inclusive for all students.

\section{Conclusion}

Disproportionality in school discipline and achievement by race has been a longstanding problem. The development of promising intervention to create environments that are equitable and supportive is exciting. Promising approaches are beginning to mature and take hold. The field of education is seeing progression in improving outcomes for all student 


\section{APPENDIX A}

\section{CULTURALLY RESPONSIVE - CLASSROOM OBSERVATION CHECKLIST}

\section{(CR-COC)}

\begin{tabular}{|c|c|c|c|c|}
\hline Element & Never & Inconsistent & Consistent & $\mathbf{N} / \mathbf{A}$ \\
\hline \multicolumn{5}{|c|}{ Teaching Culturally Responsive Expectations } \\
\hline 1. Expectations are posted & Not Posted & & Posted & \\
\hline $\begin{array}{l}\text { 2. States clear expectations before } \\
\text { directions. (e.g., when we start } \\
\text { our math lesson, I want you to } \\
\text { have your voices off and your } \\
\text { materials out and ready, if you } \\
\text { need help please raise your hand.) }\end{array}$ & $\begin{array}{l}\text { Never states } \\
\text { specific } \\
\text { behavioral } \\
\text { expectations } \\
\text { during the } \\
\text { observation. }\end{array}$ & $\begin{array}{c}\text { States } \\
\text { expectations } \\
\text { for some but } \\
\text { not all } \\
\text { activities. }\end{array}$ & $\begin{array}{c}\text { States } \\
\text { expectations } \\
\text { for all } \\
\text { activities. }\end{array}$ & \\
\hline $\begin{array}{l}\text { 3. States or refers to class-wide or } \\
\text { school-wide expectations }\end{array}$ & $\begin{array}{l}\text { Never states or } \\
\text { refers to posted } \\
\text { expectations. }\end{array}$ & $\begin{array}{l}\text { States or refers } \\
\text { to posted } \\
\text { expectations } \\
\text { for some but } \\
\text { not all } \\
\text { activities. }\end{array}$ & $\begin{array}{l}\text { States or } \\
\text { refers to } \\
\text { posted } \\
\text { expectations } \\
\text { for all } \\
\text { activities }\end{array}$ & $\begin{array}{l}\text { Expectations } \\
\text { are not } \\
\text { posted }\end{array}$ \\
\hline \multicolumn{5}{|l|}{ Praise } \\
\hline $\begin{array}{l}\text { 4. Greets students at the door by } \\
\text { name. }\end{array}$ & Greets & & Doesn't greet & $\begin{array}{l}\text { Entering is } \\
\text { not observed }\end{array}$ \\
\hline $\begin{array}{l}\text { 5. Uses or refers to more than one } \\
\text { strategy to acknowledge student } \\
\text { behavior (e.g., praise, point } \\
\text { system) }\end{array}$ & $\begin{array}{l}\text { Uses only one } \\
\text { strategy (e.g., } \\
\text { verbal praise) }\end{array}$ & & $\begin{array}{l}\text { Uses or refers } \\
\text { to more than } \\
\text { one strategy } \\
\text { (e.g., points, } \\
\text { tickets, } \\
\text { praise, } \\
\text { gestures). }\end{array}$ & \\
\hline $\begin{array}{l}\text { Provides praise/acknowledgement } \\
\text { more frequently than correction }\end{array}$ & $\begin{array}{c}\text { Correction is } \\
\text { more frequent } \\
\text { than } \\
\text { acknowledgement } \\
\text { for AA and Other } \\
\text { Students } \\
\end{array}$ & $\begin{array}{l}\text { Praise is more } \\
\text { frequent than } \\
\text { correction for } \\
\text { AA or Other } \\
\text { Students }\end{array}$ & $\begin{array}{l}\text { Praise is more } \\
\text { frequent than } \\
\text { correction for } \\
\text { both AA or } \\
\text { Other } \\
\text { Students }\end{array}$ & \\
\hline $\begin{array}{l}\text { 7. When problems occur, uses praise } \\
\text { around strategy. }\end{array}$ & $\begin{array}{l}\text { Does not use } \\
\text { praise around } \\
\text { strategy }\end{array}$ & $\begin{array}{c}\text { Uses praise } \\
\text { around } \\
\text { strategy, but } \\
\text { has missed } \\
\text { opportunities to } \\
\text { use praise } \\
\text { around strategy }\end{array}$ & $\begin{array}{l}\text { Uses praise } \\
\text { around } \\
\text { strategy every } \\
\text { time when } \\
\text { appropriate }\end{array}$ & $\begin{array}{l}\text { No problem } \\
\text { behavior }\end{array}$ \\
\hline $\begin{array}{l}\text { 8. Scans and interacts with students } \\
\text { throughout the observation }\end{array}$ & $\begin{array}{l}\text { Teacher stays at } \\
\text { desk or only } \\
\text { interacts with one } \\
\text { student or group } \\
\text { of students }\end{array}$ & $\begin{array}{l}\text { Scans the room } \\
\text { but spends a } \\
\text { significant } \\
\text { amount of time } \\
\text { with a few } \\
\text { students }\end{array}$ & $\begin{array}{l}\text { Constantly } \\
\text { scans the } \\
\text { room and } \\
\text { interacts with } \\
\text { the entire } \\
\text { class (i.e., } \\
\text { does not get }\end{array}$ & \\
\hline
\end{tabular}




\begin{tabular}{|c|c|c|c|c|}
\hline & & & $\begin{array}{l}\text { bogged } \\
\text { down). }\end{array}$ & \\
\hline $\begin{array}{l}\text { 9. Moves around between students } \\
\text { during the observation. }\end{array}$ & $\begin{array}{l}\text { Teacher remains } \\
\text { in one area } \\
\text { throughout the } \\
\text { observation }\end{array}$ & $\begin{array}{c}\text { Teacher moves } \\
\text { around but } \\
\text { spends a } \\
\text { significant } \\
\text { amount of time } \\
\text { in one location }\end{array}$ & $\begin{array}{c}\text { Teacher } \\
\text { covers the } \\
\text { whole room } \\
\text { and does not } \\
\text { get bogged } \\
\text { down }\end{array}$ & $\begin{array}{l}\text { Carpet time } \\
\text { or small } \\
\text { group }\end{array}$ \\
\hline \multicolumn{5}{|l|}{ Reprimands } \\
\hline $\begin{array}{l}\text { 10. Uses more than one strategy to } \\
\text { correct student behavior } \\
\text { (modeling, proximity) }\end{array}$ & $\begin{array}{l}\text { Teacher only } \\
\text { provides verbal } \\
\text { correction }\end{array}$ & & $\begin{array}{l}\text { Teacher uses } \\
\text { multiple } \\
\text { strategies to } \\
\text { correct } \\
\text { behavior } \\
\text { (e.g., } \\
\text { proximity, } \\
\text { crouching by } \\
\text { student, } \\
\text { verbal } \\
\text { correction, } \\
\text { modeling, } \\
\text { gesturing). }\end{array}$ & $\begin{array}{l}\text { No } \\
\text { Corrections }\end{array}$ \\
\hline $\begin{array}{l}\text { 11. Corrects behavior quickly, } \\
\text { explicitly, quietly, \& as } \\
\text { situationally inappropriate, not } \\
\text { wrong. }\end{array}$ & $\begin{array}{l}\text { Consistently uses } \\
\text { harsh reprimands } \\
\text { to correct } \\
\text { behavior. }\end{array}$ & $\begin{array}{l}\text { Generally, } \\
\text { corrects } \\
\text { behavior } \\
\text { explicitly, but } \\
\text { has harsh } \\
\text { reprimands. }\end{array}$ & $\begin{array}{l}\text { Does not use } \\
\text { harsh } \\
\text { reprimands }\end{array}$ & $\begin{array}{l}\text { No } \\
\text { Corrections }\end{array}$ \\
\hline $\begin{array}{l}\text { 12. Provides specific feedback or } \\
\text { practice in response to social and } \\
\text { academic behavior errors }\end{array}$ & $\begin{array}{c}\text { Teacher } \\
\text { frequently does } \\
\text { not state desired } \\
\text { behavior (e.g., } \\
\text { Shhh, no don't) } \\
\text { when correcting } \\
\text { behavior. }\end{array}$ & $\begin{array}{c}\text { Teacher has } \\
\text { students model } \\
\text { desired } \\
\text { behavior and } \\
\text { states desired } \\
\text { behavior when } \\
\text { correcting } \\
\text { about half the } \\
\text { time. }\end{array}$ & $\begin{array}{c}\text { Teacher has } \\
\text { students } \\
\text { model desired } \\
\text { behavior and } \\
\text { states desired } \\
\text { behavior } \\
\text { when } \\
\text { correcting } \\
\text { almost every } \\
\text { time. }\end{array}$ & $\begin{array}{l}\text { No } \\
\text { Corrections }\end{array}$ \\
\hline 13. Uses friendly and firm tone. & $\begin{array}{l}\text { Teacher uses } \\
\text { harsh tone } \\
\text { consistently }\end{array}$ & $\begin{array}{c}\text { Teacher } \\
\text { generally uses } \\
\text { a friendly tone, } \\
\text { but also uses a } \\
\text { harsh tone. }\end{array}$ & $\begin{array}{c}\text { Teacher does } \\
\text { not use a } \\
\text { harsh tone } \\
\text { when } \\
\text { correcting }\end{array}$ & $\begin{array}{l}\text { No } \\
\text { Corrections }\end{array}$ \\
\hline 14. De-escalates Conflicts & $\begin{array}{c}\text { Teacher escalates } \\
\text { conflicts that } \\
\text { occur. }\end{array}$ & $\begin{array}{c}\text { Teacher does } \\
\text { not de-esclate } \\
\text { conflicts, but } \\
\text { does not make } \\
\text { it worse. }\end{array}$ & $\begin{array}{c}\text { Teacher } \\
\text { effectively } \\
\text { de-escalates } \\
\text { conflicts }\end{array}$ & $\begin{array}{l}\text { No conflicts } \\
\text { occur }\end{array}$ \\
\hline
\end{tabular}




\section{APPENDIX B}

PRIMARY INTERVENTION RATING SCALE (Lane, et al. 2009)

The purpose of this survey is to obtain information to improve this intervention approach. Please check the box that best describes your agreement or disagreement with each statement.

\begin{tabular}{|c|c|c|c|c|c|c|}
\hline & $\begin{array}{c}1 \\
\text { Strongly } \\
\text { Disagree }\end{array}$ & $\begin{array}{c}2 \\
\text { Disagree }\end{array}$ & $\begin{array}{c}3 \\
\text { Slightly } \\
\text { Disagree }\end{array}$ & $\begin{array}{c}4 \\
\text { Slightly } \\
\text { Agree }\end{array}$ & $\begin{array}{c}5 \\
\text { Agree }\end{array}$ & $\begin{array}{c}6 \\
\text { Strongly } \\
\text { Agree }\end{array}$ \\
\hline $\begin{array}{l}\text { 1. This would be an acceptable } \\
\text { intervention for the school. }\end{array}$ & & & & & & \\
\hline $\begin{array}{l}\text { 2. Most teachers would find this } \\
\text { intervention appropriate }\end{array}$ & & & & & & \\
\hline $\begin{array}{l}3 \text { This intervention should prove } \\
\text { effective in meeting the purposes. }\end{array}$ & & & & & & \\
\hline $\begin{array}{l}\text { 4. I would suggest the use of this } \\
\text { intervention to other teachers. }\end{array}$ & & & & & & \\
\hline $\begin{array}{l}\text { 5. This intervention is appropriate to } \\
\text { meet the school's needs and mission. }\end{array}$ & & & & & & \\
\hline $\begin{array}{l}\text { 6. Most teachers would find this } \\
\text { intervention suitable for the described } \\
\text { purposes and mission. }\end{array}$ & & & & & & \\
\hline $\begin{array}{l}\text { 7. I would be willing to use this } \\
\text { intervention in the school setting. }\end{array}$ & & & & & & \\
\hline $\begin{array}{l}\text { 8. This intervention would not result in } \\
\text { negative side-effects for the students. }\end{array}$ & & & & & & \\
\hline $\begin{array}{l}\text { 9. This intervention would be appropriate } \\
\text { for a variety of students. }\end{array}$ & & & & & & \\
\hline $\begin{array}{l}\text { 10. This intervention is consistent with } \\
\text { those I have used in school settings. }\end{array}$ & & & & & & \\
\hline $\begin{array}{l}\text { 11. This intervention is a fair way to } \\
\text { fulfill the intervention purposes. }\end{array}$ & & & & & & \\
\hline $\begin{array}{l}\text { 12. This intervention plan is reasonable } \\
\text { to meet the stated purposes. }\end{array}$ & & & & & & \\
\hline $\begin{array}{l}\text { 13. I like the procedures used in this } \\
\text { intervention. }\end{array}$ & & & & & & \\
\hline $\begin{array}{l}\text { 14. This intervention is a good way to } \\
\text { meet the specified purpose. }\end{array}$ & & & & & & \\
\hline $\begin{array}{l}\text { 15. The monitoring procedures are } \\
\text { manageable. }\end{array}$ & & & & & & \\
\hline $\begin{array}{l}\text { 16. The monitoring procedures will give } \\
\text { the necessary information to evaluate the } \\
\text { plan. }\end{array}$ & & & & & & \\
\hline $\begin{array}{l}\text { 17. Overall, this intervention would be } \\
\text { beneficial for elementary/K-8 students. }\end{array}$ & & & & & & \\
\hline
\end{tabular}




\section{Your Comments}

What do you like about the intervention content (WHAT we shared)?

How could the content be improved?

What do you like about the proposed delivery (HOW we shared it)?

How could the delivery be improved?

What kinds of coaching or ongoing assistance do you think would increase its use in schools?

THANK YOU FOR SHARING YOUR PERSPECTIVE! 


\section{APPENDIX C}

\section{COACH CONTACT LOG}

\begin{tabular}{|c|c|c|}
\hline Coded Fields & Codes & Description \\
\hline Scheduling - Baseline & SB & Time spent setting up meetings during baseline phase. \\
\hline Scheduling - Intervention & SI & $\begin{array}{l}\text { Time spent setting up meetings during intervention } \\
\text { phase. }\end{array}$ \\
\hline Teacher Interview & $\mathrm{TI}$ & Time spent doing Intake teacher interview. \\
\hline Baseline Data Collection & $\mathrm{BDC}$ & $\begin{array}{l}\text { Time spent in the classroom doing data collection and } \\
\text { completing the data forms in the baseline phase. }\end{array}$ \\
\hline $\begin{array}{l}\text { Intervention Data } \\
\text { Collection }\end{array}$ & IDC & $\begin{array}{l}\text { Time spent in the classroom doing data collection and } \\
\text { completing the data forms in the intervention phase. }\end{array}$ \\
\hline Providing Feedback & PF & $\begin{array}{l}\text { Time spent providing feedback through email or printed } \\
\text { copy using the feedback form and graphs (i.e., not } \\
\text { feedback during the Follow-up Meetings). }\end{array}$ \\
\hline Initial Action Planning & IAP & $\begin{array}{l}\text { Time spent using and completing the goal setting and } \\
\text { action planning sections during the Action Planning } \\
\text { Meeting. }\end{array}$ \\
\hline Follow-up Action Planning & FAP & $\begin{array}{l}\text { Time spent using and completing the goal setting and } \\
\text { action planning sections during Follow-up Meetings. }\end{array}$ \\
\hline Initial Feedback & IF & $\begin{array}{l}\text { Time spent meeting with the teacher regarding the data } \\
\text { review (i.e., fidelity and outcome data) during the } \\
\text { Action Planning Meeting. }\end{array}$ \\
\hline Follow-up Feedback & $\mathrm{FF}$ & $\begin{array}{l}\text { Time spent meeting with the teacher regarding data } \\
\text { review (i.e., fidelity and outcome data) during the } \\
\text { Follow-up Meetings. }\end{array}$ \\
\hline $\begin{array}{l}\text { Coach Prep for Feedback - } \\
\text { Action Planning }\end{array}$ & CPFAP & $\begin{array}{l}\text { Time spent in school, at home, or by phone } \\
\text { preparing/compiling the data, making feedback ratings, } \\
\text { and practicing for feedback sessions for Action Planning } \\
\text { Meeting. }\end{array}$ \\
\hline $\begin{array}{l}\text { Coach Prep for Feedback - } \\
\text { Follow-up }\end{array}$ & CPFF & $\begin{array}{l}\text { Time spent in school, at home, or by phone } \\
\text { preparing/compiling the data, making feedback ratings, } \\
\text { and practicing for feedback sessions for Follow-up } \\
\text { Meetings. }\end{array}$ \\
\hline Planning time with teacher & PT & $\begin{array}{l}\text { Any in-depth strategy design and planning with teacher } \\
\text { beyond action planning (e.g., creating lessons, role-play, } \\
\text { etc.). }\end{array}$ \\
\hline Modeling with class & M & $\begin{array}{l}\text { Modeling of strategies for the teacher that are done } \\
\text { with the entire classroom or small group. }\end{array}$ \\
\hline Other & 0 & \\
\hline
\end{tabular}




\section{APPENDIX D \\ TEACHER INTAKE INTERVIEW \\ *Be sure to record the code and time in minutes for each coaching activity \\ I. Informed consent}

Explain the purpose and expectations of the study. Greet the teacher and provide a brief explanation of the study using the IRB consent forms as a guide.

*Provide an opportunity for the teacher to ask questions about the study, without revealing what the intervention is, and address any concerns they have.

*If teacher is willing, have them sign the informed consent document. If the teacher is not willing to participate in the study, thank them for their time and end the interview.

Time in minutes:

\section{Teacher Experience}

Opening dialogue with teacher. "In addition to going over the study and getting your consent to participate, I wanted to meet with you briefly to ask you a few questions. These questions will allow me to get to know you better and give me an idea of your classroom management style. We will also talk a little bit about any past experiences you have had in receiving feedback and support to improve your teaching. Before we start, do you have any questions?"

1. What was it that made you want to become a teacher?

2. How long have you been a teacher? Have you always taught this grade level?

3. What do you think is the best thing about being a teacher?

4. What do you find to be the most challenging thing about being a teacher? 
*Provide a brief summary of the discussion so far. You can also build rapport

by connecting personally and normalizing the challenges faced by the

Time in minutes:

\section{Card Sort Activity}

"Now I would like to do an activity together. It is fun and will let me get to know you better. I have a set of cards (show the teacher the cards). Each card has a value or quality listed on the front. I would like you to go through the cards and sort them into three piles. You will make a pile of cards that represent values or qualities that are most important to you, somewhat important, and less important. When you are done we will talk about the cards you have selected as most important."

\section{*Conduct the Card Sort activity}

Write down the top 3 most important values to the teacher:

1.

2.

3.

*Provide a brief summary of the values discussion.

Time in minutes:

\section{Classroom Management Style}

"Now I am going to ask you a few questions about how you manage student behavior in your classroom."

1. How would you describe your current classroom management style?

What do you consider to be areas of strength with regard to your management style? 
What are some challenges that you face?

2. Do you have classroom rules? If so, what are those rules?

3. Do you use reward systems in your classroom? If so, what do those systems look like?

4. How do you manage misbehavior in your classroom?

5. When working with a student with difficult behavior, what strategies have you found to be most effective for you? What strategies have you found to be ineffective?

*Provide a brief summary of the discussion in this section. You can also connect to the teacher by giving examples of shared experiences (if brief and appropriate)

Time in minutes: 


\section{Discussion of Ideal Classroom}

1. If you were to picture your ideal classroom, what would that look like?

2. What do you hope the students in your classroom remember about you?

*Provide a brief summary that connects to earlier stated values if relevant.

Time in minutes:

\section{Past Experiences}

"I have just a few more questions about your experiences you have had in the past with coaching, mentoring, or with someone giving you feedback and working with you to improve your teaching."

1. What has been your past experience with coaching or mentoring?

What did you find helpful?

What, if anything, did you find not helpful?

*Provide a summary. 


\section{Next Steps}

"Let me briefly describe what we will be doing together. The first thing I would like to do is come to your classroom and observe. During the observation, I will be gathering information that will help us to figure out what specific strategies you might want to try out in your classroom. Any of the information I gather will only be shared with you and not used to evaluate you in any way. After I gather this information we will meet to review it together. We will look to see if there are any areas that you want to improve or identify a new strategy you might want to try in your classroom. I will also come back to visit to see how things are going. Do you have any questions or concerns?"

Time in minutes:

\section{Set Up Observation Time}

"Let's set up a good time for me to observe. Observations will be about 30 minutes long and I would like to come in during a time where you have the most difficulty with managing behavior. Ideally this is a time where you have a consistent schedule of for instruction. When might be a good time for you?"

\begin{tabular}{|l|l|l|l|l|}
\hline Subject & $\begin{array}{c}\text { Scheduled } \\
\text { Start time }\end{array}$ & $\begin{array}{c}\text { Scheduled } \\
\text { End time }\end{array}$ & $\begin{array}{c}\text { Length in } \\
\text { minutes }\end{array}$ & Special notes \\
\hline & & & & \\
& & & & \\
\hline
\end{tabular}

Time in minutes:

Code: Scheduling 


\begin{abstract}
APPENDIX E
ACTION PLANNING MEETING

*Be sure to record the code and time in minutes for each coaching activity
\end{abstract}

\title{
I. Action Planning Meeting Preparation (Completed before the meeting)
}

Steps to prepare for this meeting:

1. Insert teacher praise and reprimand graph into section III. Data Review.

2. Fill out Teacher Feedback Form based on observations from the Culturally Responsive Classroom Observation Checklist

3. Bring (a) Blank Classroom Matrix, (b) Classroom Matrix Examples, (c) Personal Matrix Activity, (d) Neutralizing Routine Poster Examples, and (e) Neutralizing Routine Lesson Plan Examples for action planning.

Time in minutes: Code: Coach Prep for Feedback

\section{Review}

Review the purpose of the study. Greet the teacher and provide a brief review of the purpose of the study and the observation procedure thus far. Explain that today we will be reviewing the data collected and planning intervention.

*Provide an opportunity for the teacher to ask questions.

\section{Data Review}

*Review data with the teacher. Be sure to thoroughly explain each graph and elicit/respond to any clarifying questions.

\section{Praise and Reprimand Rates}

[Insert Praise and Reprimand graph]

*Reflect on the differences for Black students compared to all other students in the

\section{Fidelity of Implementation Feedback}

*Explain the fidelity data discussed in this next section will inform action planning. It can help identify what the teacher is already doing well and potential strategies to improve outcomes (the data from the section above). 
Put an X for each item on the Area of Strength - Needs Attention continuum

\begin{tabular}{|l|l|}
\hline \multicolumn{2}{|l|}{ Teaching Culturally Responsive Expectations } \\
\hline Expectations are posted & \\
\hline States clear expectations before directions. & \\
\hline $\begin{array}{l}\text { States or refers to class-wide or school-wide } \\
\text { expectations }\end{array}$ & \\
\hline Precorrects before VDPs. & \\
\hline Other: & \\
\hline
\end{tabular}

\begin{tabular}{|l|l|}
\multicolumn{2}{c}{ Attention } \\
\hline Praise
\end{tabular}

\section{Reprimands}

Uses more than one strategy to correct student behavior (modeling, proximity)

Corrects behavior quickly, explicitly, quietly, \& as situationally inappropriate, not wrong. Provides specific feedback or practice in response to social and academic behavior errors Uses friendly and firm tone.

De-escalates Conflicts

Other:

Attention 
Time in minutes: Code: Initial Feedback

\section{Action Planning}

*Complete an action plan with the teacher. Be sure to reference the fidelity checklist for potential action items. Additionally, explain the activities of a personal matrix and teaching neutralizing routines. State that you will send feedback after each observation on Praise and Reprimands and on the areas of the teacher feedback form. If motivation is waning, go back to

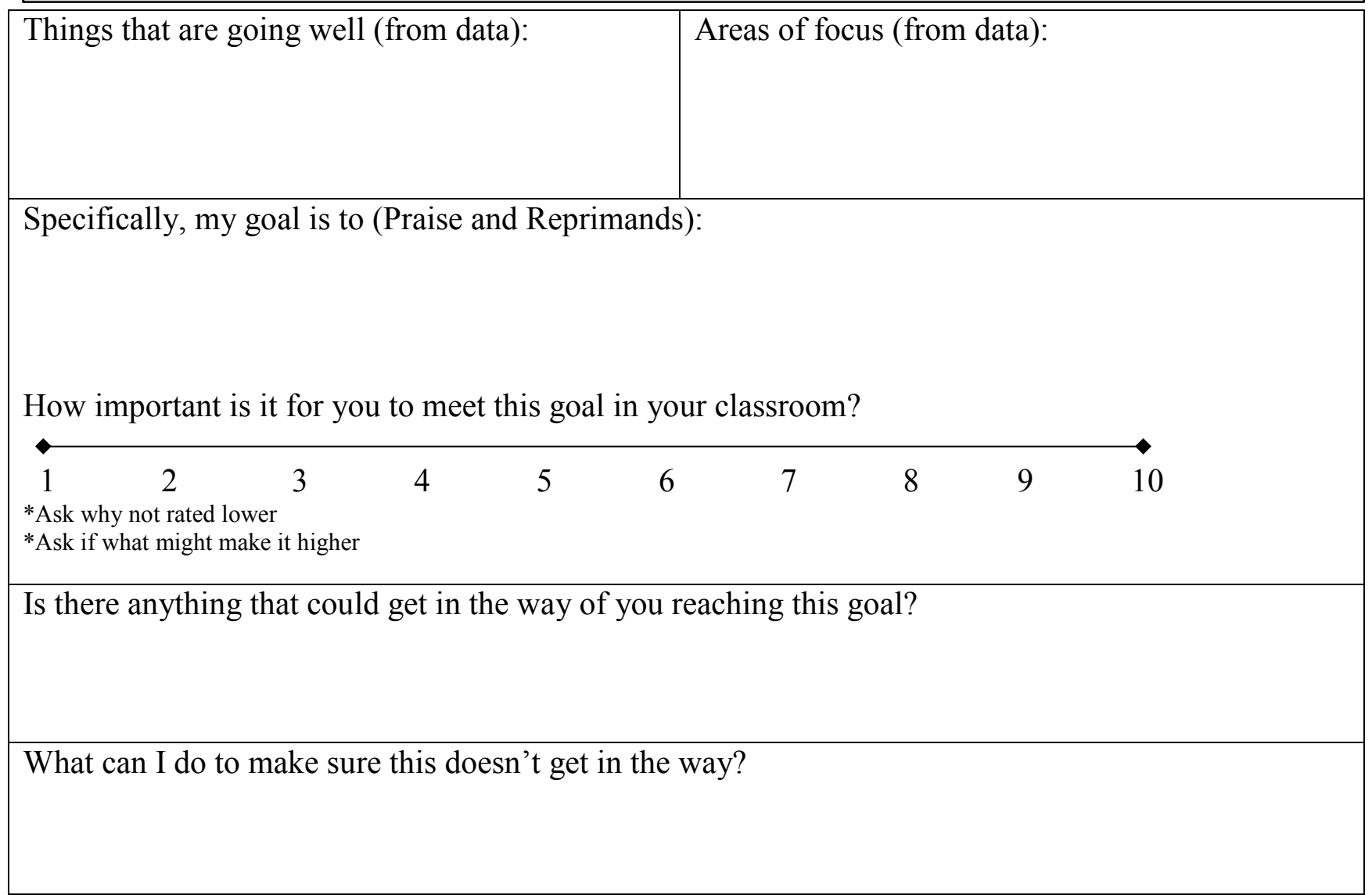




\begin{tabular}{|c|c|c|c|c|c|}
\hline \multicolumn{2}{|c|}{ Solution Development } \\
$\begin{array}{c}\text { Solution } \\
\text { Components }\end{array}$ & $\begin{array}{c}\text { What are } \\
\text { the action } \\
\text { steps? }\end{array}$ & $\begin{array}{c}\text { Who is } \\
\text { Responsible? }\end{array}$ & By When? & $\begin{array}{c}\text { How will fidelity } \\
\text { be measured? }\end{array}$ & Notes/Updates \\
\hline \begin{tabular}{c|c|c|c|} 
Expectations \\
Praise
\end{tabular} & & & & \\
\hline Reprimands & & $\begin{array}{c}\text { Who is } \\
\text { responsible for } \\
\text { gathering the } \\
\text { data? }\end{array}$ & When/How often will data be \\
\hline gathered?
\end{tabular}

*Provide a review of the action items and state that you will be sending this form to them so they have it. Discuss and remedy any lingering issues in the action plan.

Time in minutes: Code: Initial Action Planning

\section{Set Up Follow-up Meeting Time}

"Let's set up a good time for us to follow-up and see how things are going within a week. We will review our data and our action plan and adjustments as needed. I will continue to observe and provide feedback. What day and time works for you?"

Next meeting:

\begin{tabular}{|l|l|l|l|}
\hline Date & Time & Location & Special notes \\
\hline & & & \\
& & & \\
& & & \\
\hline
\end{tabular}

Time in minutes: Code: Scheduling 


\section{APPENDIX F}

STUDENT PERSONAL MATRIX ACTIVITY (from Leverson et al., 2016)

A personal matrix (or behavior dictionary) is a tool classroom teachers can use to draw on student prior knowledge regarding behavior expectations (Validate and Affirm) and identify where connections need to be bridged and built. School personnel articulate expectations in the school setting, and students are asked to reflect on expectations in other settings in their lives. This dictionary can be used to help reteach and to help students learn to code-switch while allowing teachers to learn how the expectations may have been taught to fluency previously.

In the example below, the school wide expectations are identified and are operationalized in the "at school" column for students. Students are then asked to complete the At Home and In my Neighborhood columns individually.

This activity allows school personnel to check for prior knowledge and understand where there may be cultural gaps between home and school, and where additional instruction may be necessary.

\begin{tabular}{|c|c|c|c|}
\hline $\begin{array}{l}\text { School-wide } \\
\text { Expectation }\end{array}$ & $\begin{array}{l}\text { At SCHOOL } \\
\text { It looks like... }\end{array}$ & $\begin{array}{c}\text { At HOME } \\
\text { It looks like... }\end{array}$ & $\begin{array}{c}\text { In my NEIGHBORHOOD } \\
\text { it looks like... }\end{array}$ \\
\hline Be Safe & $\begin{array}{l}\text { - Keep hands and feet } \\
\text { to self } \\
\text { - Tell an adult if there is } \\
\text { a problem }\end{array}$ & $\begin{array}{l}\text { Protect your friends } \\
\text { and family } \\
\text { - Don't talk back }\end{array}$ & $\begin{array}{l}\text { - Stick up for } \\
\text { your friends } \\
\text { - Don't back down } \\
\text { - Look the other way }\end{array}$ \\
\hline Be Respectful & $\begin{array}{l}\text { Treat others how you } \\
\text { want to be treated } \\
\text { - Include others } \\
\text { - Listen to adults }\end{array}$ & $\begin{array}{l}\text { - Do exactly what adults } \\
\text { tell you to do } \\
\text { - Don't stand out } \\
\text { - Don't bring shame }\end{array}$ & $\begin{array}{l}\text { - Text back within } 30 \\
\text { seconds } \\
\text { - Be nice to } \\
\text { friends' parents } \\
\text { - Share food }\end{array}$ \\
\hline Be Responsible & $\begin{array}{l}\text { - Do my own work } \\
\text { - Personal best } \\
\text { - Follow directions } \\
\text { - Clean up messes }\end{array}$ & $\begin{array}{l}\text { - Help your family out } \\
\text { first } \\
\text { - Own your mistakes } \\
\text { - Share credit for } \\
\text { successes }\end{array}$ & $\begin{array}{l}\text { - Have each } \\
\text { other's backs } \\
\text { - Own your mistakes } \\
\text { - Check in about what } \\
\text { to do }\end{array}$ \\
\hline
\end{tabular}


APPENDIX G

PRAISE PREFERENCE ASSESSMENT ACTIVITY

Acknowledgement strategies used by the teacher during observations:
1. WOW Tickets
2. Class Chain
3. Praise around
4. Praise for academics
5. Praise for behaviors

Are there any strategies I missed?

Are there any other strategies that you would like to use but haven't yet? 


\section{Student Praise Preference Assessment Activity}

Put a star by your favorite and an X by any you don't like

\begin{tabular}{|l|l|}
\hline My favorite when I do something good is when & \\
\hline Our class gets a chain & \\
\hline I get a WOW! ticket & \\
\hline My teacher tells me I did a good job & \\
\hline My teacher gives me a smile or a thumbs up & \\
\hline & \\
\hline & \\
\hline & \\
\hline
\end{tabular}

I wish my teacher knew: 


\section{APPENDIX H}

\section{FOLLOW-UP MEETING}

*Be sure to record the code and time in minutes for each coaching activity

\section{Follow-up Meeting Preparation (Completed before the meeting)}

Steps to prepare for this meeting:

1. Bring copy of previous action plan to reference in section III.

4. Insert teacher praise and reprimand graph into section II. Data Review.

5. Fill out Teacher Feedback Form based on observations from the Culturally Responsive - Classroom Observation Checklist

6. Bring other materials needed for action planning

Time in minutes: Code: Coach Prep for Feedback -Follow-up

\section{Data Review}

*Review data with the teacher. Be sure to thoroughly explain each graph and elicit/respond to any clarifying questions.

\section{Praise and Reprimand Rates}

[Insert Praise and Reprimand graph]

*Reflect on the differences for Black students compared to all other students in the

\section{Fidelity of Implementation Feedback}

*Explain the fidelity data discussed in this next section will inform action planning. It can help identify what the teacher is already doing well and potential strategies to improve outcomes (the data from the section above).

Put an X for each item on the Area of Strength - Needs Attention continuum *If N/A leave blank

\begin{tabular}{|l|l|}
\hline \multicolumn{2}{|l|}{ Teaching Culturally Responsive Expectations } \\
\hline Expectations are posted & \\
\hline States clear expectations before directions. & \\
\hline $\begin{array}{l}\text { States or refers to class-wide or school-wide } \\
\text { expectations }\end{array}$ & \\
\hline Precorrects before VDPs. & \\
\hline Other: & \\
\hline
\end{tabular}




\begin{tabular}{|l|l|}
\hline \multicolumn{2}{|l|}{ Praise } \\
\hline Greets students at the door by name. & \\
\hline $\begin{array}{l}\text { Uses or refers to more than one strategy to } \\
\text { acknowledge student behavior (e.g., praise, } \\
\text { point system) }\end{array}$ & \\
\hline $\begin{array}{l}\text { Provides praise/acknowledgement more } \\
\text { frequently than correction }\end{array}$ & \\
\hline $\begin{array}{l}\text { When problems occur, uses praise around } \\
\text { strategy. }\end{array}$ & \\
\hline $\begin{array}{l}\text { Scans and interacts with students throughout the } \\
\text { observation }\end{array}$ & \\
\hline $\begin{array}{l}\text { Moves around between students during the } \\
\text { observation. }\end{array}$ & \\
\hline Other: & \\
\hline
\end{tabular}

\begin{tabular}{|l|l|}
\hline \multicolumn{2}{|l|}{ Reprimands } \\
\hline $\begin{array}{l}\text { Uses more than one strategy to correct student } \\
\text { behavior (modeling, proximity) }\end{array}$ & \\
\hline $\begin{array}{l}\text { Corrects behavior quickly, explicitly, quietly, \& } \\
\text { as situationally inappropriate, not wrong. }\end{array}$ & \\
\hline $\begin{array}{l}\text { Provides specific feedback or practice in } \\
\text { response to social and academic behavior errors }\end{array}$ & \\
\hline Uses friendly and firm tone. & \\
\hline De-escalates Conflicts & \\
\hline Other: & \\
\hline & Area of Strength \\
\hline
\end{tabular}

Time in minutes: Code: Follow-up Feedback

\section{Action Planning}

\section{Review Previous Action Plan}

Were any action items that were not completed? Yes No

List the items:

*Discuss reasons and barriers to implementation of action items. Go back to 


\section{Create New Action Plan}

*Complete an action plan with the teacher. Be sure to reference the fidelity checklist for potential action items. Additionally, explain the activities of a personal matrix and teaching neutralizing routines. State that you will send feedback after each observation on Praise and Reprimands and on the areas of the

\begin{tabular}{|l|l|}
\hline Things that are going well (from data): & Areas of focus (from data): \\
\hline
\end{tabular}

Specifically, my goal is to (Praise and Reprimands):

How important is it for you to meet this goal in your classroom?

\begin{tabular}{lllllllll}
\hline 1 & 2 & 4 & 5 & 6 & 7 & 8 & 9 & 10 \\
*Ask why not rated lower \\
*Ask if what might make it higher
\end{tabular}

Is there anything that could get in the way of you reaching this goal?

What can I do to make sure this doesn't get in the way?

\begin{tabular}{|c|c|c|c|c|c|}
\hline \multicolumn{5}{|c|}{ Solution Development } \\
\hline $\begin{array}{c}\text { Solution } \\
\text { Components }\end{array}$ & $\begin{array}{c}\text { What are } \\
\text { the action } \\
\text { steps? }\end{array}$ & $\begin{array}{c}\text { Who is } \\
\text { Responsible? }\end{array}$ & By When? & $\begin{array}{c}\text { How will } \\
\text { fidelity be } \\
\text { measured? }\end{array}$ & Notes/Updates \\
\hline $\begin{array}{c}\text { Teach CR } \\
\text { Expectations }\end{array}$ & & & & & \\
\hline Praise & & & & & \\
\hline Reprimands & & & & \\
\hline & \multicolumn{2}{|c|}{$\begin{array}{c}\text { Who is } \\
\text { look at? }\end{array}$} & $\begin{array}{c}\text { Wesponsible for } \\
\text { gathering the }\end{array}$ & $\begin{array}{c}\text { When/How often will data be } \\
\text { gathered? }\end{array}$ \\
\hline
\end{tabular}




\begin{tabular}{|c|l|l|l|}
\hline & data? & \\
\hline $\begin{array}{c}\text { Data } \\
\text { Collection }\end{array}$ & & & \\
\hline
\end{tabular}

*Have the teacher rate each action item and discuss any barriers to implementation.

\section{Set Up Follow-up Meeting Time}

*Follow-up meetings are needed if goals are not met and/or greater fidelity of implementation is needed.

"Let's set up a good time for us to follow-up and see how things are going within a week. We will review our data and our action plan and adjustments as needed. I will continue to observe and provide feedback. What day and time works for you?"

Next meeting:

\begin{tabular}{|l|l|l|l|}
\hline Date & Time & Location & Special notes \\
\hline & & & \\
& & & \\
& & & \\
\hline
\end{tabular}

Time in minutes: Code: Scheduling 


\section{REFERENCES CITED}

American Psychological Association. (2008). Are zero tolerance policies effective in the schools? An evidentiary review and recommendations. American Psychologist, $63,852-862$.

Anyon, Y., Jenson, J. M., Altschul, I., Farrar, J., McQueen, J., Greer, E., . . . Simmons, J. (2014). The persistent effect of race and the promise of alternatives to suspension in school discipline outcomes. Children and Youth Services Review, 44, 379-386.

Bradshaw, C. P., Mitchell, M. M., O'Brennan, L. M., \& Leaf, P. J. (2010). Multilevel exploration of factors contributing to the overrepresentation of black students in office disciplinary referrals. Journal of Educational Psychology, 102, 508-520.

Bradshaw, C. P., Pas, E. T., Bottiani, J. H., Debnam, K. J., Reinke, W. M., Herman, K. C., \& Rosenberg, M. S. (2018). Promoting cultural responsivity and student engagement through Double Check coaching of classroom teachers: An efficacy study. School Psychology Review, 47(2), 118-134.

Cohen, J. (1977). Statistical power analysis for the behavioral sciences (Rev. ed.). Hillsdale, NJ, US: Lawrence Erlbaum Associates, Inc.

Cook, C. R., Duong, M. T., McIntosh, K., Fiat, A. E., Larson, M., Pullmann, M. D., \& McGinnis, J. (2018). Addressing discipline disparities for Black male students: Linking malleable root causes to feasible and effective practices. School Psychology Review, 47(2), 135-152.

Ekstrom, R., Goertz, M., Pollack, J., \& Rock, D. (1986). Who drops out of high school and why? Findings from a national study. The Teachers College Record, 87, 356373.

Floress, M. T., Jenkins, L. N., Reinke, W. M., \& McKown, L. (2017). General education teachers' natural rates of praise: A preliminary investigation. Behavioral Disorders, 0198742917709472.

Gion, C., McIntosh, K., \& Horner, R. (2014). Patterns of minor office discipline referrals in schools using SWIS PBIS Evaluation Brief. OSEP National Technical Assistance Center on Positive Behavioral Interventions and Supports. Eugene, OR.

Girvan, E. J., Gion, C., McIntosh, K., \& Smolkowski, K. (2016). The relative contribution of subjective office referrals to racial disproportionality in school discipline. School Psychology Quarterly, No Pagination Specified. doi: $10.1037 /$ spq0000178 
Gregory, A., Hafen, C. A., Ruzek, E., Mikami, A. Y., Allen, J. P., \& Pianta, R. C. (2016). Closing the racial discipline gap in classrooms by changing teacher practice. School Psychology Review, 45(2), 171-191.

Gregory, A., Skiba, R. J., \& Noguera, P. A. (2010). The achievement gap and the discipline gap: Two sides of the same coin? Educational Researcher, 39, 59-68. doi:10.3102/0013189x09357621

Hedges, L. V., Pustejovsky, J. E., \& Shadish, W. R. (2013). A standardized mean difference effect size for multiple baseline designs across individuals. Research Synthesis Methods, 4, 324-341.

Irvin, L. K., Tobin, T. J., Sprague, J. R., Sugai, G., \& Vincent, C. G. (2004). Validity of office discipline referral measures as indices of school-Wide behavioral status and effects of school-wide behavioral interventions. Journal of Positive Behavior Interventions, 6(3), 131-147.

Kratochwill, T., R. , Hitchcock, J., H., Horner, R., H., Levin, J., R., Odom, S., L. , Rindskopf, D., M., \& Shadish, W., R. . (2013). Single-case intervention research design standards. Remedial and Special Education, 34(1), 26-38. doi: $10.1177 / 0741932512452794$

Leverson, M., Smith, K., McIntosh, K., Rose, J., \& Pinkelman, S. (2016). PBIS cultural responsiveness field guide: Resources for trainers and coaches.

Losen, D. J., Hodson, C., Keith, M. A., Morrison, K., \& Belway, S. (2015). Are we closing the school discipline gap? Center for Civil Rights Remedies at The Civil Rights Project at UCLA. Los Angeles, CA.

MacSuga, A. S., \& Simonsen, B. (2011). Increasing teachers' use of evidence-based classroom management strategies through consultation: Overview and case studies. Beyond Behavior, 20(2), 4-12.

MacSuga-Gage, A. S., \& Simonsen, B. (2015). Examining the effects of teacher-directed opportunities to respond on student outcomes: A systematic review of the literature. Education and Treatment of Children, 38(2), 211-239.

May, S. L., Ard, W. I., Todd, A. W., Horner, R. H., Glasgow, A., Sugai, G., \& Sprague, J. R. (2013). School-Wide Information System. Educational and Community Supports, University of Oregon, Eugene, OR. Retrieved from http:/www.pbisapps.org

McIntosh, K., Ellwood, K., McCall, L., \& Girvan, E. J. (2018). Using Discipline Data to Enhance Equity in School Discipline. Intervention in School and Clinic, 53(3), $146-152$. 
McIntosh, K., Gion, C., \& Bastable, E. (2018). Do schools implementing SWPBIS have decreased racial and ethnic disproportionality in school discipline? PBIS Evaluation Brief. OSEP National Technical Assistance Center on Positive Behavioral Interventions and Supports. Eugene, OR.

McIntosh, K., Girvan, E. J., Horner, R. H., \& Smolkowski, K. (2014). Education not incarceration: A conceptual model for reducing racial and ethnic disproportionality in school discipline. Journal of Applied Research on Children, $5,1-22$.

Miller, W. R., \& Rollnick, S. (2002). Motivational interviewing: Preparing people for change (2nd ed.). New York, NY: Guilford Press.

Nicholson-Crotty, S., Birchmeier, Z., \& Valentine, D. (2009). Exploring the impact of school discipline on racial disproportion in the juvenile justice system. Social Science Quarterly, 90, 1003-1018.

Patterson, G. R. (1982). Coercive family process. Eugene, OR: Castalia Publishing. Raffaele Mendez, L. M. (2003). Predictors of suspension and negative school outcomes: A longitudinal investigation. New Directions for Youth Development, 2003(99), 17-33.

Reinke, W. M., Herman, K. C., \& Newcomer, L. (2016). The brief student-teacher classroom interaction observation: Using dynamic indicators of behaviors in the classroom to predict outcomes and inform practice. Assessment for Effective Intervention, 42(1), 32-42.

Reinke, W. M., Herman, K. C., \& Sprick, R. (2011). Motivational interviewing for effective classroom management: The classroom check-up. New York: Guilford Press.

Reinke, W. M., Lewis-Palmer, T., \& Merrell, K. (2008). The Classroom Check-up: A classwide teacher consultation model for increasing praise and decreasing disruptive behavior. School Psychology Review, 37(3), 315-332.

Reinke, W. M., Stormont, M., Herman, K. C., Wachsmuth, S., \& Newcomer, L. (2015). The Brief Classroom Interaction Observation-Revised: An observation system to inform and increase teacher use of universal classroom management practices. Journal of Positive Behavior Interventions, 17(3), 159-169.

Rocque, M. (2010). Office discipline and student behavior: Does race matter? American Journal of Education, 116(4), 557-581. 
Scheirer, M. A. (2005). Is sustainability possible? A review and commentary on empirical studies of program sustainability. American Journal of Evaluation, 26, 320-347.

Scott, T. M., Gage, N., Hirn, R., \& Han, H. (2018). Teacher and student race as a predictor for negative feedback during instruction. School Psychology Quarterly, Advance online publication. . doi:10.1037/spq0000251

Simonsen, B., Fairbanks, S., Briesch, A., Myers, D., \& Sugai, G. (2008). Evidence-based practices in classroom management: Considerations for research to practice. Education and Treatment of Children, 31(3), 351-380.

Skiba, R. J., Chung, C. G., Trachok, M., Baker, T. L., Sheya, A., \& Hughes, R. L. (2014). Parsing disciplinary disproportionality: Contributions of infraction, student, and school characteristics to out-of-school suspension and expulsion. American Educational Research Journal, 51(4), 640-670. doi:10.3102/0002831214541670

Smolkowski, K., Girvan, E., J., Mcintosh, K., Nese, R., \& Horner, R., H. (2016). Vulnerable decision points for disproportionate office discipline referrals: Comparisons of discipline for African American and White elementary school students. Behavioral Disorders, 41(4), 178-195. doi:10.17988/bedi-41-04-178195.1

Sugai, G., \& Horner, R. H. (2002). The evolution of discipline practices: School-wide positive behavior supports. Child and Family Behavior Therapy, 24, 23-50.

Sugai, G., \& Horner, R. H. (2009). Defining and describing schoolwide positive behavior support. In W. Sailor, G. Dunlap, G. Sugai, \& R. H. Horner (Eds.), Handbook of positive behavior support (pp. 307-326). New York: Springer.

Sugai, G., Horner, R. H., \& McIntosh, K. (2008). Best practices in developing a broadscale system of support for school-wide positive behavior support. In A. Thomas \& J. P. Grimes (Eds.), Best practices in school psychology V (pp. 765-780). Bethesda, MD: National Association of School Psychologists.

Taie, S., \& Goldring, R. (2017). Characteristics of public elementary and secondary school teachers in the United States: Results from the 2015-16 National Teacher and Principal Survey. First Look. NCES 2017-072. National Center for Education Statistics.

Tobin, T. J., Sugai, G., \& Colvin, G. (1996). Patterns in middle school discipline records. Journal of Emotional and Behavioral Disorders, 4, 82-94. 
Vincent, C. G., Swain-Bradway, J., Tobin, T. J., \& May, S. (2011). Disciplinary referrals for culturally and linguistically diverse students with and without disabilities:

Patterns resulting from school-wide positive behavior support. Exceptionality, 19, 175-190.

Vincent, C. G., \& Tobin, T. J. (2011). The relationship between implementation of School-Wide Positive Behavior Support (SWPBS) and disciplinary exclusion of students from various ethnic backgrounds with and without disabilities. Journal of Emotional and Behavioral Disorders, 19, 217-232. doi:10.1177/1063426610377329

Wiltsey Stirman, S., Kimberly, J., Cook, N., Calloway, A., Castro, F., \& Charns, M. (2012). The sustainability of new programs and innovations: a review of the empirical literature and recommendations for future research. Implement Sci, 7, 717. doi:10.1186/1748-5908-7-17 